\title{
Snow depth in eastern Europe in relation to circulation patterns
}

\author{
Ewa BEDNORZ, ${ }^{1}$ Joanna WIBIG ${ }^{2}$ \\ ${ }^{1}$ Department of Climatology, Institute of Physical Geography and Environmental Planning, Adam Mickiewicz University, \\ 61-680 Poznań, Dzięgielowa 27, Poland \\ E-mail: ewabedno@amu.edu.pl \\ ${ }^{2}$ Department of Meteorology and Climatology, University of Łódź, 90-139 Łódź, Narutowicza 88, Poland
}

\begin{abstract}
Rotated principal components of the $500 \mathrm{hPa}$ geopotential heights in the Euro-Atlantic sector are used as indicators of circulation pattern intensity. Daily snow-cover depth data for the years 1951-95 from 71 eastern European stations are examined. Maps of linear correlation coefficient between monthly change in snow depth and rotated principal components are presented. The positive and negative extremes of each circulation pattern are analyzed, and positive and negative snow-depth signals indicated. A daily analysis of relationships between snow depth and circulation pattern is performed for three locations. The strongest impact of the atmospheric circulation on changes in snow depth is observed in the south and west of the study area, where the eastern European (EE) and central European circulation patterns are found to have the greatest impact. The North Atlantic Oscillation (NAO) impact on the snow depth in eastern Europe is limited to the beginning and the end of winter. Snow cover has low variability in northeastern Europe (where the Scandinavian (SC) pattern is of greatest importance) and low sensitivity to change in the atmospheric circulation. The decrease in snowcover depth observed in spring is related to the NAO, SC and EE patterns, the latter being important for snow-cover depth fluctuations over northeastern Europe in April.
\end{abstract}

\section{INTRODUCTION}

Winter climate conditions in Europe are strongly affected by the air circulation. The North Atlantic Oscillation (NAO) is the best-recognized circulation pattern determining the spatial distribution of the main climatological elements, such as temperature and precipitation (Hurrell, 1995; Hurrell and Van Loon, 1997; Wibig, 1999a, b, c, 2001). The positive phase of this bipolar circulation mode signifies a pronounced difference in the air pressure between the Icelandic-low and Azores-high centres. It causes a stronger than usual westerly airflow and intensifies cyclonic activity over Europe (Carleton, 1988; Serreze, and others 1997). Above-normal winter temperatures are observed in most of Europe during NAO positive extremes (Hurrell, 1995; Hurrell and Van Loon, 1997; Wibig, 2001). Higher than normal winter precipitation also appears in the northwestern part of the continent during the NAO positive phase (Hurrell, 1995; Wibig, 1999a, b, c, 2001).

The relationships between the NAO index and the annual number of days with snow cover or snow depth are statistically significant in central Europe (Bednorz, 2002, 2004; Falarz, 2002) but fade away towards the east. Gutzler and Rosen (1992) found that the NAO-like teleconnection pattern is the only one exhibiting appreciable correlations with anomalies of snow-cover extent over Europe. Clark and others (1999) investigated the Eurasian snow layout and its atmospheric controls on the basis of US National Oceanic and Atmospheric Administration (NOAA) weekly snow extent charts of the Northern Hemisphere. They found significant decreases in the snow cover extending over 'active' regions of central Europe in positive NAO extremes. The 'active' regions of snow-cover fluctuations are recognized by Frei (1997, cited in Clark and others, 1999; Frei and Robinson, 1999) as those where the probability of snow-cover occurrence in winter (December-February) is $10-90 \%$, in contrast to 'non-active' areas where snow cover is permanent ( $>90 \%$ probability of occurrence). Changes in the European snow extent, mainly over the 'active' regions, have also been observed during circulation patterns other than the NAO (e.g. the Eurasian type 1 (EU1) and the Siberian circulation patterns; Clark and others, 1999).

An analysis of the snow-cover response to atmospheric circulation, carried out in North America, has demonstrated that the Pacific North American (PNA) teleconnection pattern has a strong impact on snow cover. The positive phase of the PNA is associated with reduced snow cover over western North America and increased snow cover over the eastern United States (Gutzler and Rosen, 1992; Brown and Goodison, 1996; Cayan, 1996; Serreze and others 1998). Leathers and Robinson (1997) analyzed cases of abrupt changes in the seasonal cycle of North American snow cover and its atmospheric feedback.

A majority of analyses of the European snow cover and atmospheric factors controlling it have been based on weekly snow-cover extent charts derived from visible satellite imagery (Gutzler and Rosen, 1992; Clark and others 1999). The use of such data limits the possibility of considering changes in snow quantity over 'non-active' snow regions, where snow cover is a permanent phenomenon in winter. Our study is based on ground observations of changes in snow depth. Such a database provides the opportunity to observe how both 'active' and 'non-active' regions respond to atmospheric circulation.

An increase in snow-cover depth usually occurs during precipitation at an air temperature below $0^{\circ} \mathrm{C}$. Other factors (e.g. wind redistribution of snow) play a minor role. We attempt to discover circulation patterns which fulfil the above conditions, i.e. bringing simultaneously low temperature and precipitation and causing increases in snow depth. Furthermore, we try to establish which circulation patterns influence snowmelt at the end of winter in eastern Europe. The analysis is performed at a monthly time-step, and additionally, in order to revise the results of the monthly 

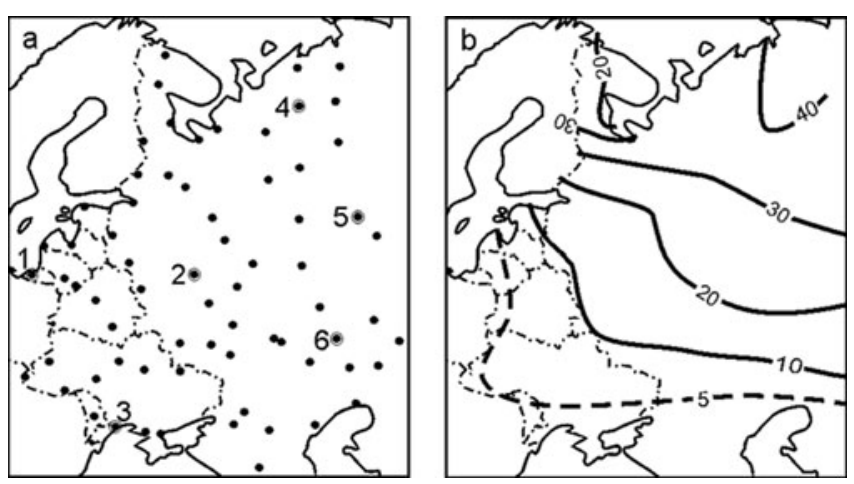

Fig. 1. (a) Location of meteorological stations from which daily data of snow-cover depth were taken for the analysis. Stations indicated with numbers appear in Figure 6. (b) Mean snow depth from November to April, based on data from the stations marked in (a) for the period 1951-95.

analysis, an investigation on a daily temporal scale is performed for three chosen locations.

\section{DATA AND METHODS}

This study is based on daily snow-depth data for 45 years from 1951 to 1995 collected at 71 eastern European stations. The data were obtained from the Historical Soviet Daily Snow Depth (HSDSD) version 2 (Armstrong, 2001). HSDSD contains quality-controlled data based on observations from the World Meteorological Organization stations located in the former Soviet Union. The investigated area covers eastern Europe between $44^{\circ}$ and $69^{\circ} \mathrm{N}$ and $20^{\circ}$ and $59^{\circ} \mathrm{E}$ (Fig. 1a). The stations are generally lower than $200 \mathrm{~m}$ a.s.l.; only nine stations have higher locations (up to $325 \mathrm{~m}$ a.s.l.).

The depth of snow is defined as the vertical distance between the top of the snow layer and the horizontal ground beneath (see the American Meteorological Society's (AMS) Glossary of Meteorology, http://amsglossary.allenpress.com). The snow-depth data are based on daily measurements taken from three snow-measuring rods. Observations are made on each rod with $1 \mathrm{~cm}$ precision. The daily mean is calculated by averaging the readings on the three rods, rounded to the nearest whole centimetre.

In order to detect changes in the snow depth, the growth of the snow depth during each day was calculated by subtracting the snow depth of a given day from that of the following day. Positive/negative values indicate increases/ decreases in snow depth. Errors caused by wind redistribution may appear while using such an approach, but may only slightly affect the monthly sum totals of positive or negative values for each month, which provided the basis for further calculations. Monthly increases/decreases in snowcover depth were calculated by summing the positive/ negative values for each month.

The term 'snowfall' is used interchangeably with 'increases in snow depth', and 'ablation' interchangeably with 'decreases in snow depth', in order to simplify the text. According to the AMS Glossary of Meteorology, 'snowfall' means the accumulation of snow during a specified period of time (usually expressed in centimetres or inches of snow depth). The term 'ablation' means the amount of snow or ice removed by the process of ablation; the opposite of accumulation. However, a decrease in snow depth refers to both ablation and snow metamorphism, i.e. increase of snow density, which may vary from 50 to $>300 \mathrm{~kg} \mathrm{~m}^{-3}$ (D. Cline, www.comet.ucar.edu/class/hydromet/09_Oct13_1999/docs/ cline/comet_snowhydro/index.htm).

To simplify the analysis, values of decreases in snow depth (always negative) were multiplied by -1 . Rikiishi and Sakakibara (2004) used the same method to detect snowdepth changes in the former Soviet Union, taking mean snow depth in pentads as a basic value. Daily changes in the snow depth in relation to atmospheric circulation types have also been investigated by Nowosad (1992) for the Bieszczady mountains territory in southeastern Poland.

To describe the circulation, a set of time series of $500 \mathrm{hPa}$ mean monthly geopotential heights was used. Each record describes the variability of $500 \mathrm{hPa}$ heights at a geographical gridpoint from $30^{\circ} \mathrm{N}$ to $70^{\circ} \mathrm{N}$ and $60^{\circ} \mathrm{W}$ to $50^{\circ} \mathrm{E}$, with a step of $2.5^{\circ}$ along the latitude and longitude. The data were derived from US National Centers for Environmental Prediction (NCEP)/US National Center for Atmospheric Research (NCAR) re-analysis (Kalnay and others, 1996). The $500 \mathrm{hPa}$ geopotential heights data, which provided the basis for defining the circulation patterns, cover the same period, 1951-95, as the snow depth data. This makes the obtained indices more accurate for our study than the indices available in NOAA Climate Prediction Center datasets (Barnston and Livezey, 1987), because the patterns obtained on the basis of principal components can change slightly with time together with changes in $500 \mathrm{hPa}$ height fields. Furthermore, the analysis is performed for a smaller region (North Atlantic and Europe), so that the obtained circulation patterns show the details of the circulation field better than those concerning the whole Northern Hemisphere. Having made the analysis, we constructed maps of correlation coefficients between rotated principal components and geopotential heights at $500 \mathrm{hPa}$ for each circulation type in each month. This allows for precise interpretation of the relationships between snow depth fluctuation and particular circulation type.

The transformation to principal components was made on the basis of the correlations between the original pairs of $500 \mathrm{hPa}$ time series in a subset composed of 30 gridpoints (with a step of $20^{\circ}$ along the parallels and $10^{\circ}$ along the meridians). The Kaiser criterion for determining the number of the principal components to rotate was used (Kaiser, 1958), their number varying from four to five during winter months. The varimax rotation was then applied to improve discrimination between loadings and to allow for distinguishing between the spatial patterns associated with the principal components obtained (Horel, 1981). The spatial patterns associated with each principal component were obtained on the basis of correlations between all the original time series and the rotated principal components.

In the analyzed part of the year, six different spatial patterns were distinguished, four of them presented in the further analysis. The most important of these is the NAO, which explains from $13.3 \%$ of the geopotential height field variance in April to $20.6 \%$ in March (Fig. 2a). It is represented by a structure of two cells with opposite sign. Their locations correspond to the mean positions of the Icelandiclow and Azores-high centres. The Scandinavian spatial pattern (SC) has one centre over the Scandinavian peninsula (Fig. 3a) and explains from $10.8 \%$ of the geopotential height field variance in February and April to $18.5 \%$ in November. The eastern European spatial pattern (EE) is a two-centre 

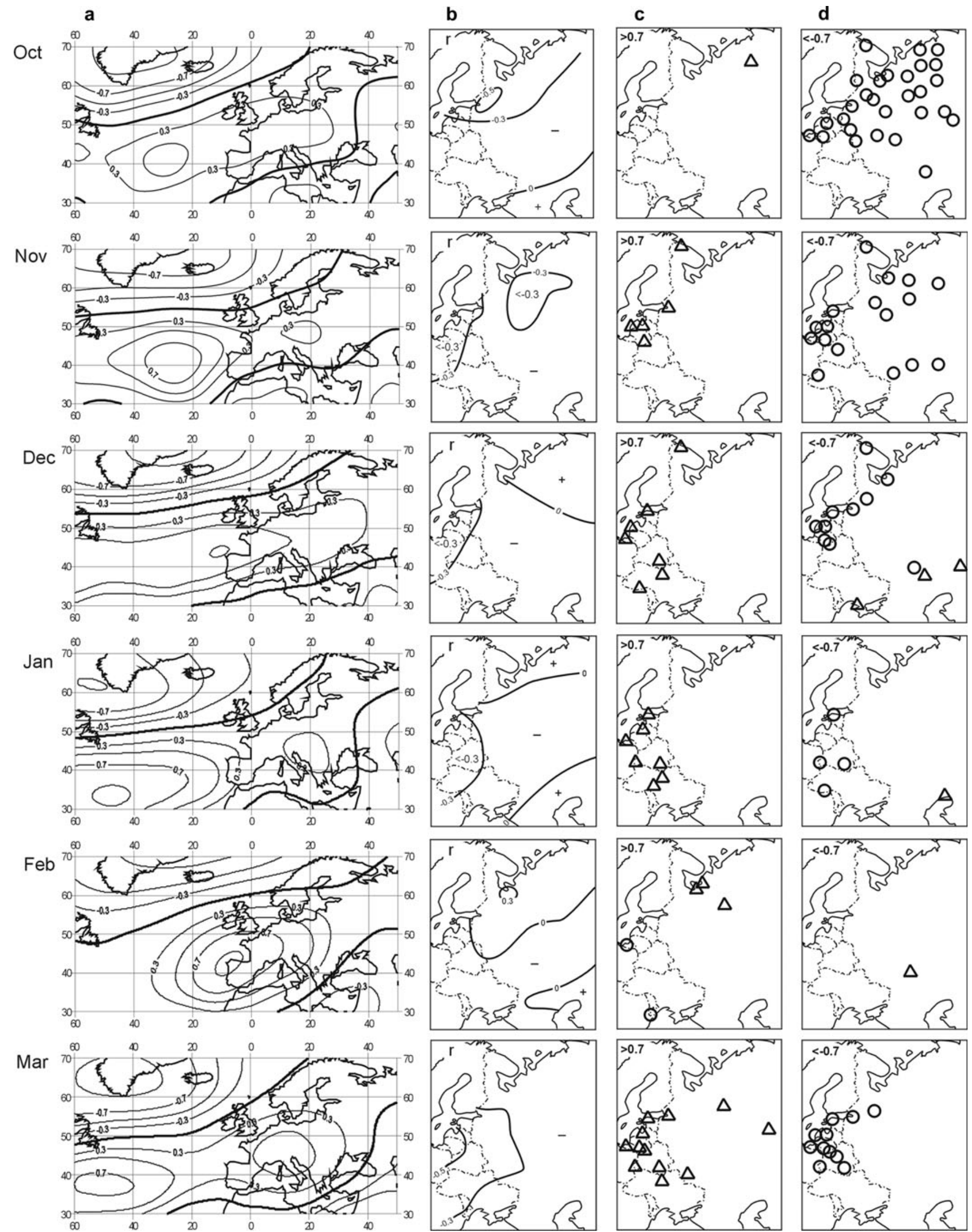

Fig. 2. The NAO pattern and its influence on snow-depth increase: (a) correlation coefficients between rotated principal components and geopotential heights at the $500 \mathrm{hPa}$ level; (b) correlation coefficients between the rotated principal components and monthly increases in snow depth; (c) increase in snow depth under positive NAO extremes; and (d) increase in snow depth under negative NAO extremes. Values higher than mean $+1 \sigma$ are indicated as circles; values lower than mean $-1 \sigma$ are indicated as triangles. 
a

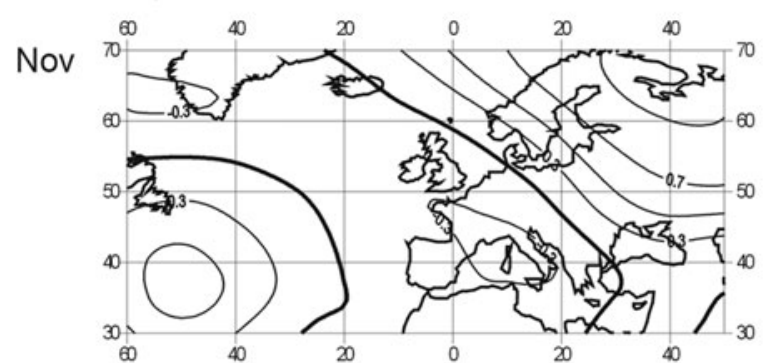

Dec

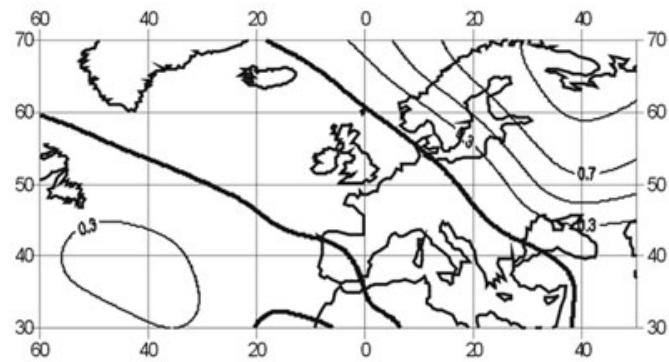

Jan

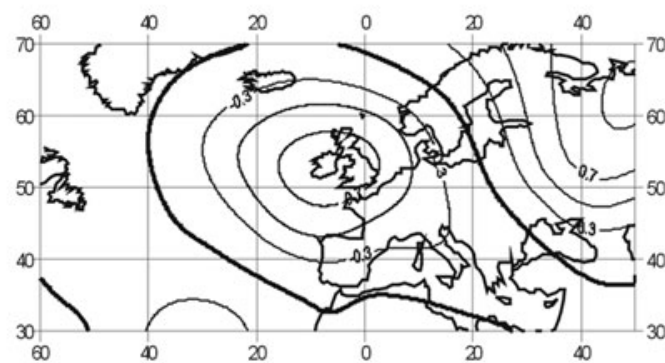

Feb

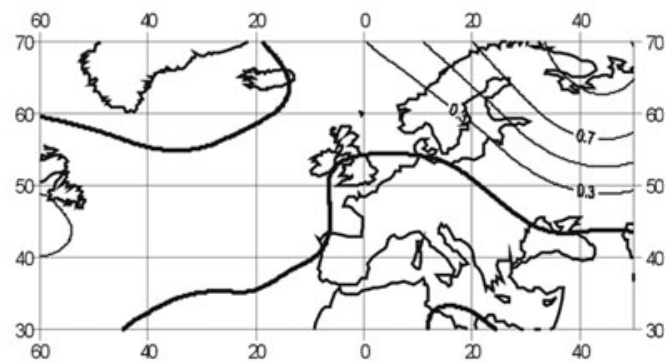

Mar

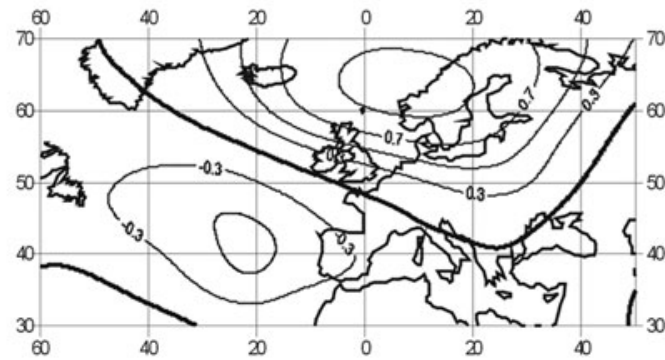

b
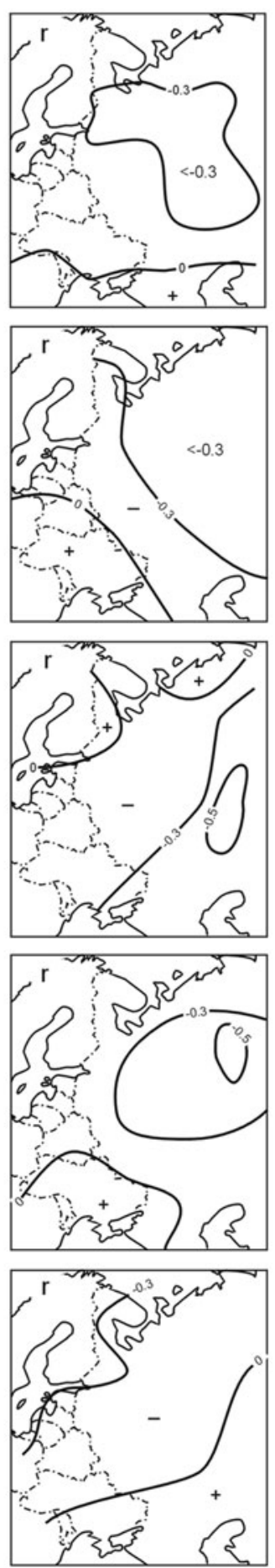

c
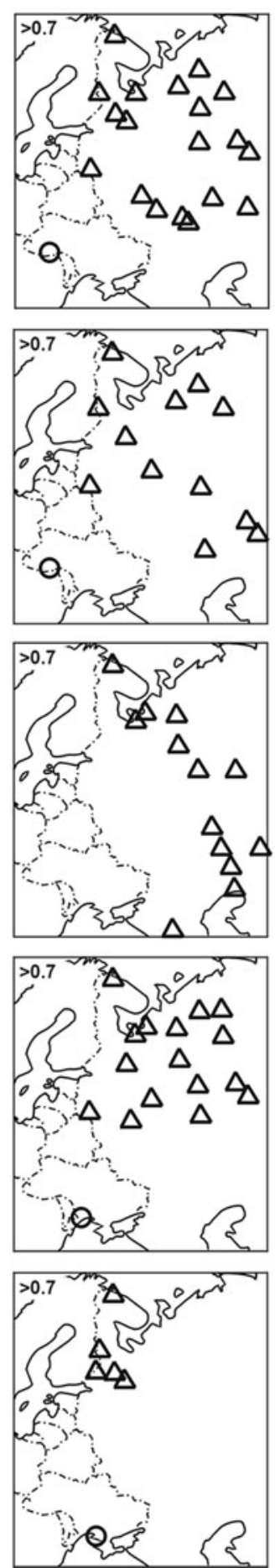
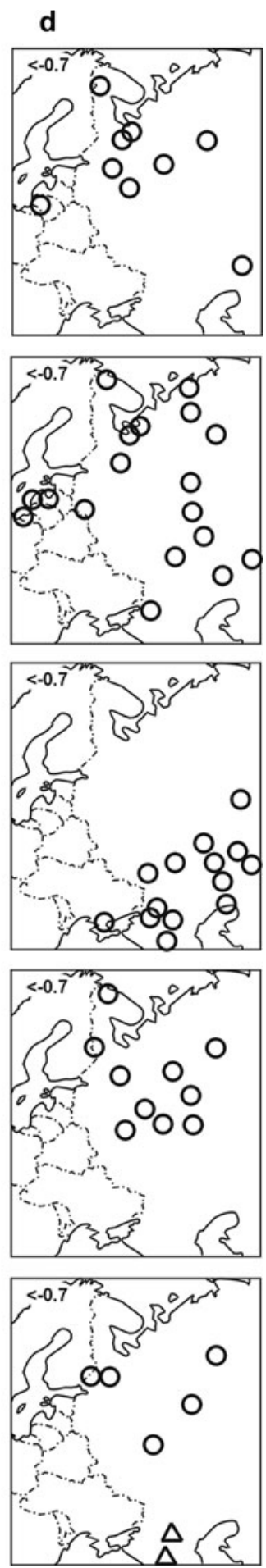

Fig. 3. The SC pattern and its influence on snow-depth increase. (a-d) as in Figure 2.

west-east pattern (Fig. 4a), with a weak western centre over Great Britain or France and its oppositely signed centre just north of the Black Sea. The central European spatial pattern (CE) has a single-cell structure centred over central Europe (Fig. 5). When the geopotential heights over this centre are high, the CE pattern is in a blocking phase. This pattern has a local character or represents part of a more complex pattern, and has not been identified before. Table 1 shows the percentages of variance explained by each of the four types of spatial pattern. The principal components presenting the normalized monthly contribution of the defined types were used as indices of circulation (Wibig, 1999b, c, 2001). All these patterns have previously been distinguished for analysis of impact of circulation on winter precipitation in Europe (Wibig, 1999a). The SC has been described by Rogers (1990).

To describe relationships between snow cover and circulation, three distinguishing characteristics of the snow cover were considered: the mean monthly snow depth, the monthly sum of increases in snow depth and the monthly sum of decreases in snow depth. The circulation patterns are not correlated with each other, so the variance of snow increase explained by the variability of all the distinguishing characteristics is the sum total of the variances explained by 
a
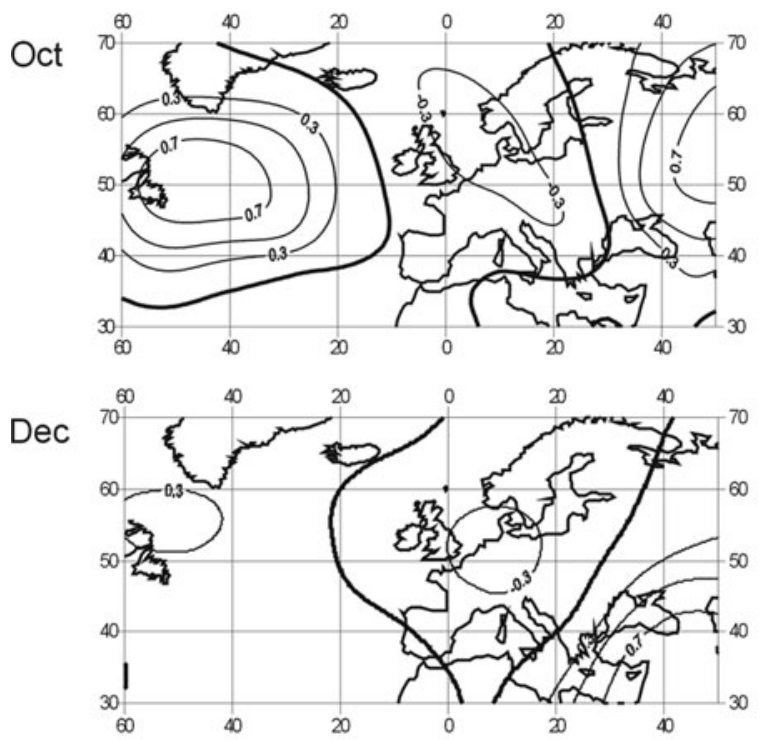

Feb

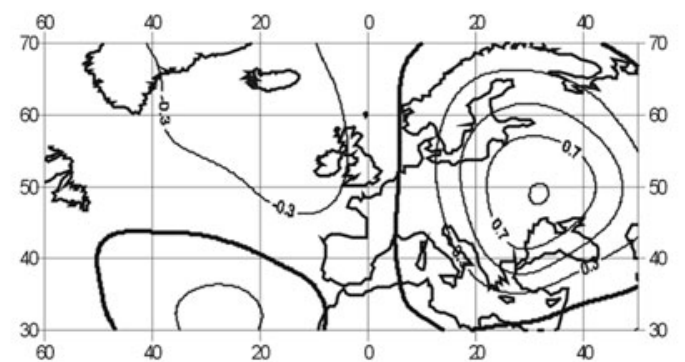

Mar

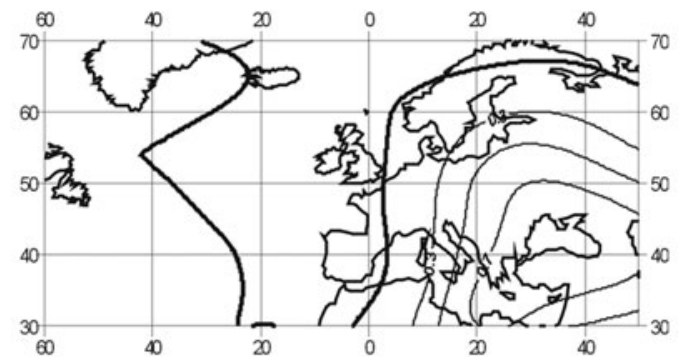

Apr

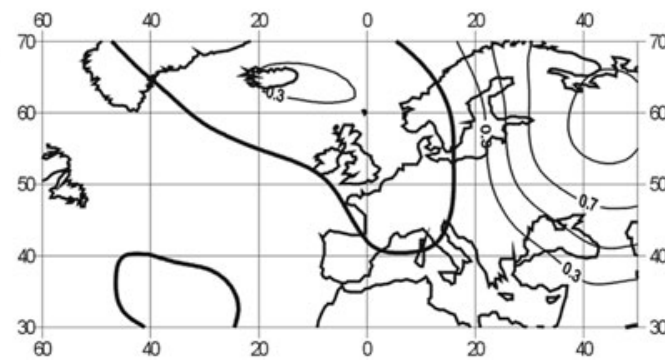

b
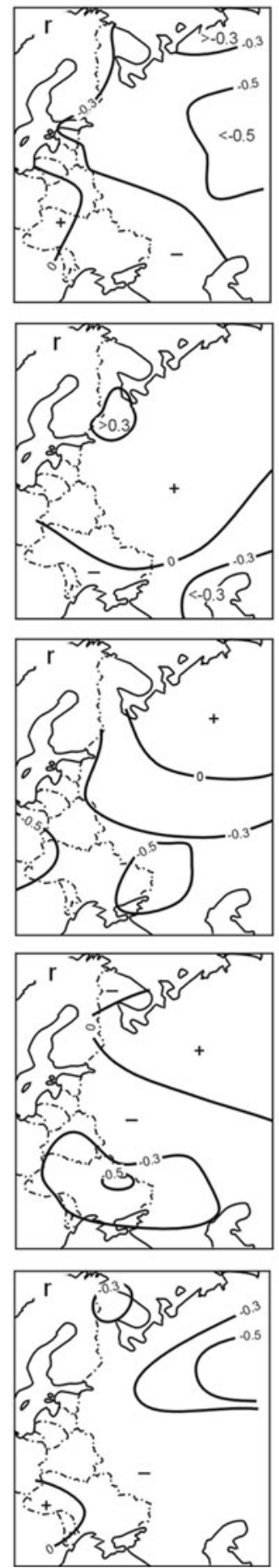

C
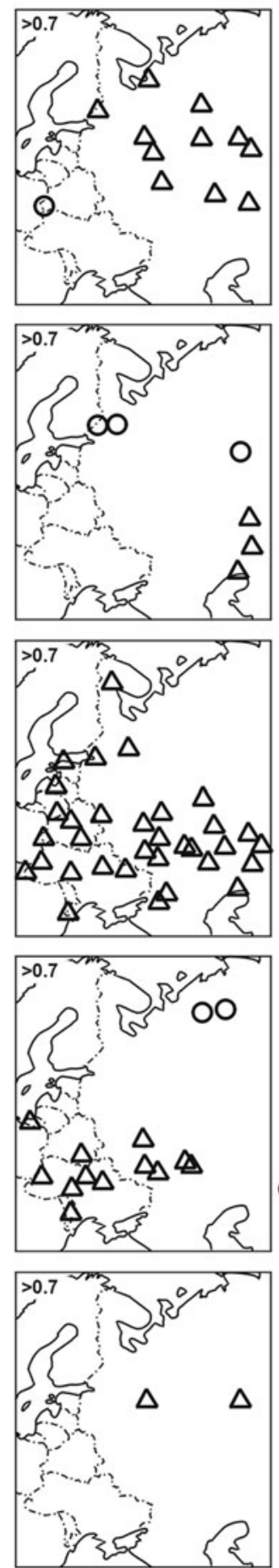

d
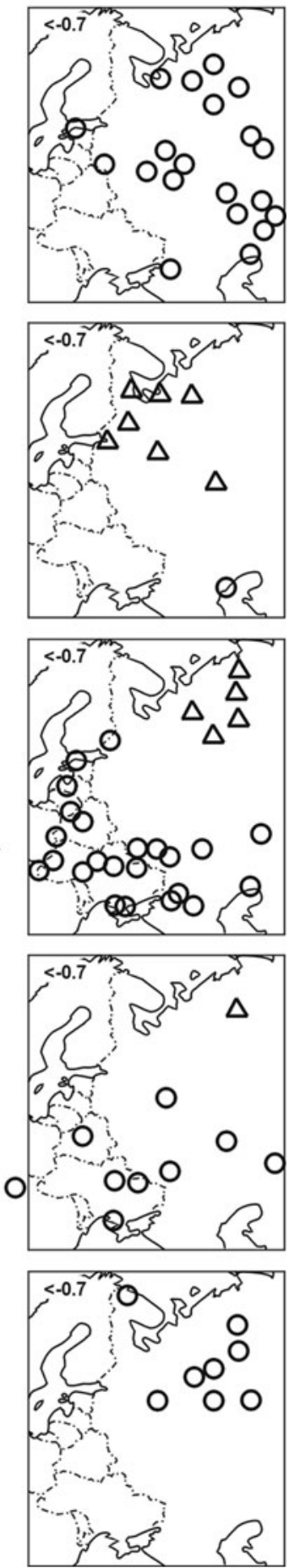

Fig. 4. The EE pattern and its influence on snow-depth increase. (a-d) as in Figure 2.

each type separately. Therefore the totals of squares of correlation coefficients between monthly increases in snow depth and all the circulation pattern indices were calculated to establish the variance of snow increase explained by the variance of each distinguishing characteristic.

The simple linear correlation coefficient $r$ is used to describe the relationships between the snow cover and circulation. Maps (Figs 2b-5b) of correlations between the principal components and the monthly sums of the increase or decrease in snow depth show the regions where the particular circulation types exerted a statistically significant influence (isolines $0.3,-0.3$ ) on the growth of the snow layer. Maps showing these correlations are constructed for October-April; however, only the maps where some statistically significant correlation appears are included in Figures $3 \mathrm{~b}-6 \mathrm{~b}$. When the absolute values of $r$ exceed 0.5 , $25 \%$ of the snow-depth increase or decrease variability can be explained by the variability in the intensity of a particular circulation type.

The positive (negative) extremes of each circulation pattern were analyzed. For each pattern, only the months with $>0.7(<-0.7)$ of the principal component were taken into consideration as extremes. Values $-0.7(0.7)$ correspond to the first (third) quartile of the principal components 


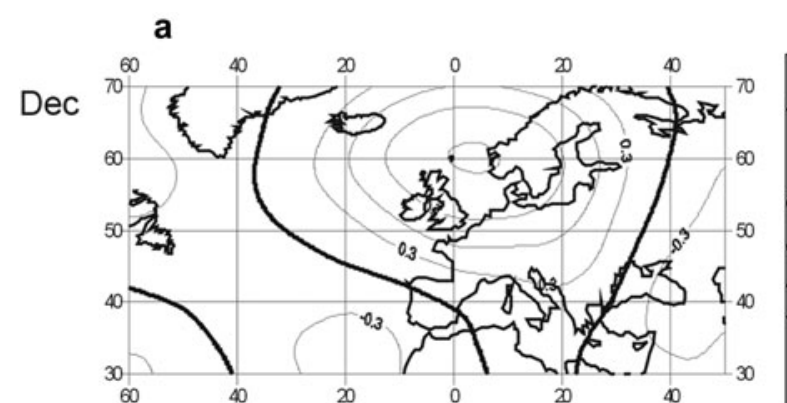

Jan

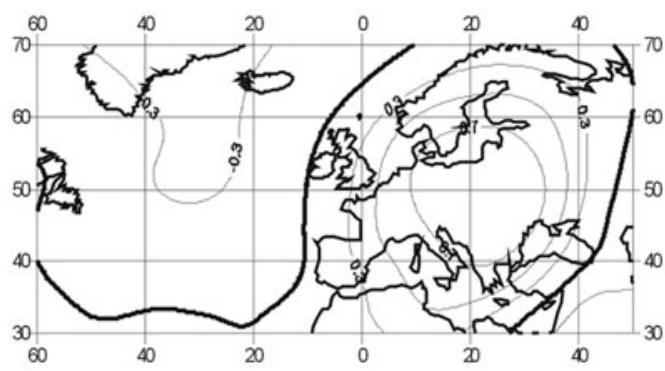

Feb

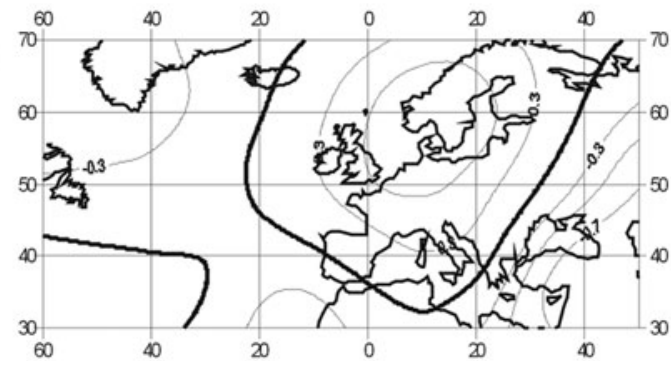

b
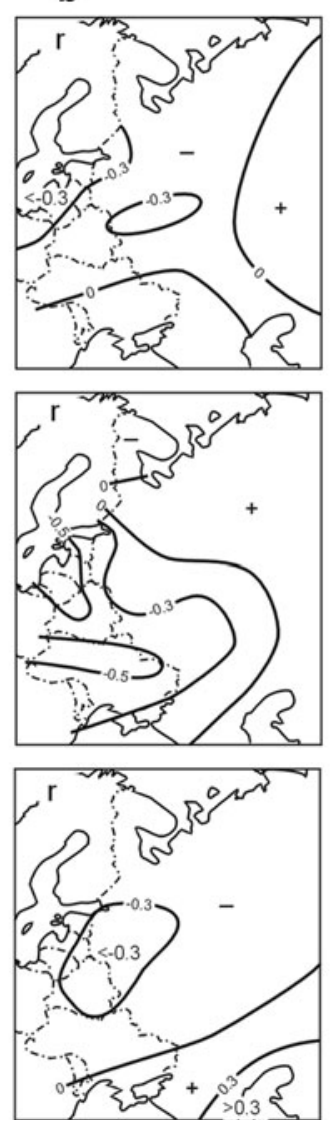

c
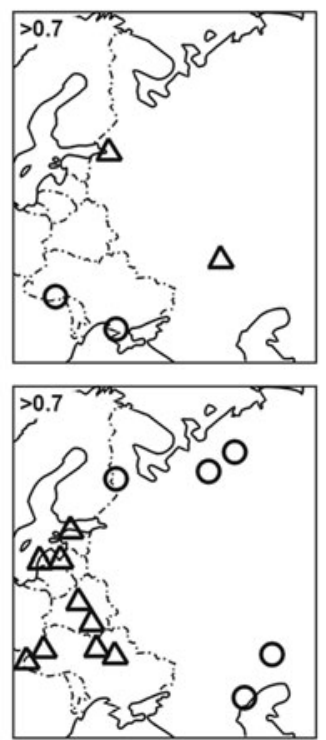

d
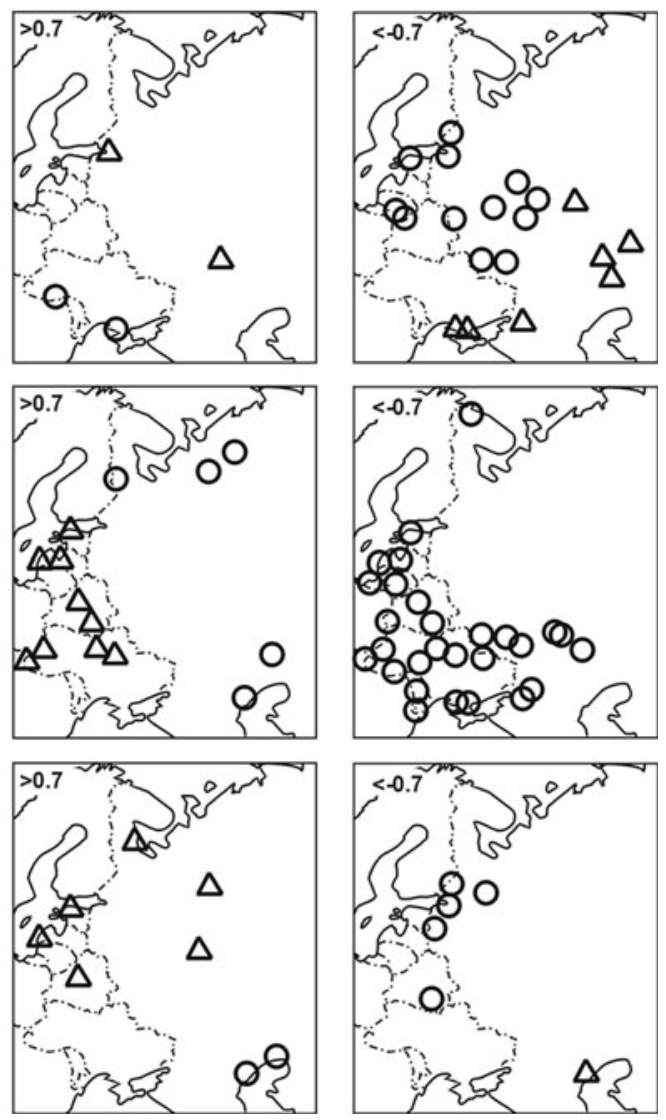

Fig. 5. The CE pattern and its influence on snow-depth increase. (a-d) as in Figure 2.

representing each pattern. The critical values for the increase or decrease of snow depth were established as (mean + $0.5 \sigma)$ or (mean $-0.5 \sigma$ ) (calculated for the entire period). The stations where the average increase (decrease) in snow depth during these months was greater (smaller) than the critical value are marked in Figures $2 c(d)-5 c(d)$.

In order to revise the results of the monthly analysis, an investigation of the daily temporal scale was performed for three stations, Kaliningrad, Ustcilma and Uralsk. Composite anomaly maps of $500 \mathrm{hPa}$ geopotential heights and sea-level pressure (SLP) were constructed for the days with snow-depth increases or decreases $>5 \mathrm{~cm}$ for each station and each month separately. Six-hourly values of $500 \mathrm{hPa}$ level were taken from NCEP/NCAR re-analysis (http://www.cru.uea. ac.uk/cru/data/pci.htm) and covered the period 1958-95. This provided the basis for calculating the daily means.

Table 1. Percentage of the total dataset variance explained by different circulation modes

\begin{tabular}{lcrrc}
\hline Month & NAO & SC & EE & CE \\
\hline Oct. & 16.1 & 17.4 & 13.0 & - \\
Nov. & 16.0 & 18.5 & 11.3 & 11.7 \\
Dec. & 20.3 & 15.7 & 9.8 & 11.8 \\
Jan. & 18.4 & 15.1 & 9.6 & 11.9 \\
Feb. & 16.4 & 10.8 & 9.7 & 14.9 \\
Mar. & 20.6 & 16.0 & 10.4 & - \\
Apr. & 13.3 & 10.8 & 13.7 & 11.0 \\
& & & & \\
\hline
\end{tabular}

Anomalies were computed as differences between the composite values and the means for the whole period. The interpretation of the contoured composite anomalies was performed in a similar way to the traditional weather anomaly maps, with clockwise (anticyclonic) flow around the positive centres and counterclockwise (cyclonic) flow around the negative centres (Birkeland and Mock, 1996).

\section{RESULTS}

Snow depth over the study area grows from the beginning of winter to achieve its maximum in March or February as shown in Figure 6, which covers the mean daily snow-depth values for the period 1951-95. Snowmelt starts in March and is particularly rapid in the 'non-active' areas (Figs $1 \mathrm{~b}$ and 6). For this reason, the monthly increases in snow depth from October to March (to April for the EE type) and the monthly decreases only from March to April were considered during further analysis.

Sum totals of squared correlation coefficients between the monthly increases in snow depth and all the circulation pattern indices exceeded 0.5 for individual stations in December, January and February (the average for the entire area was $>0.3$ ). This means that $50 \%$ of the variability in snow-depth increases can be explained by the variability in all the circulation pattern intensities in some parts of eastern Europe $(30 \%$ over the entire area). Lower values were obtained for decreases in snow depth (the maximum values for January, February and March were $0.4-0.6$ and the average for the entire area was $0.21-0.26$ ). The analyzed circulation patterns have the weakest influence on the mean 

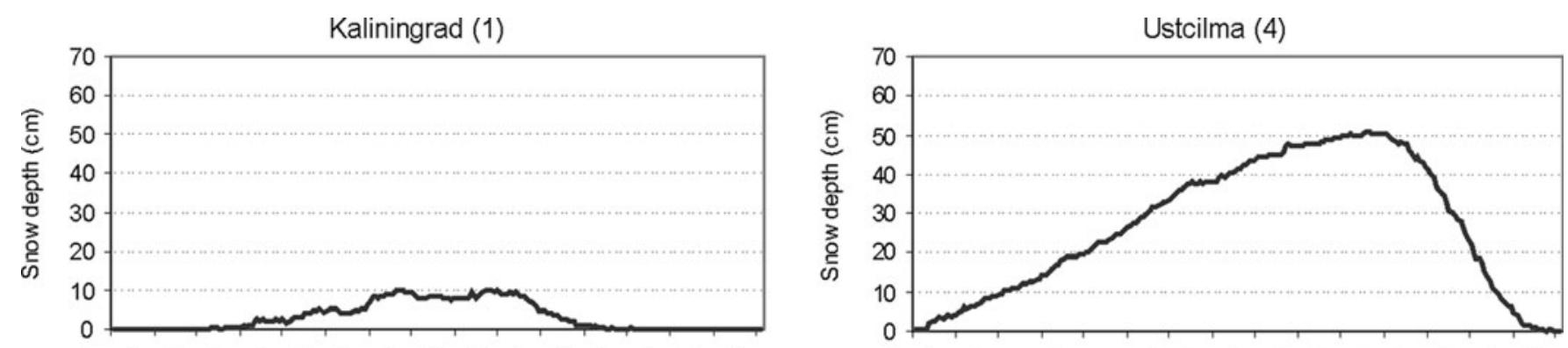

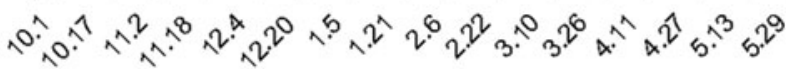

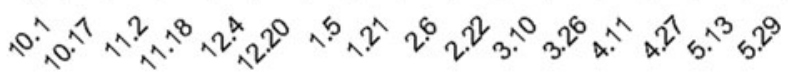
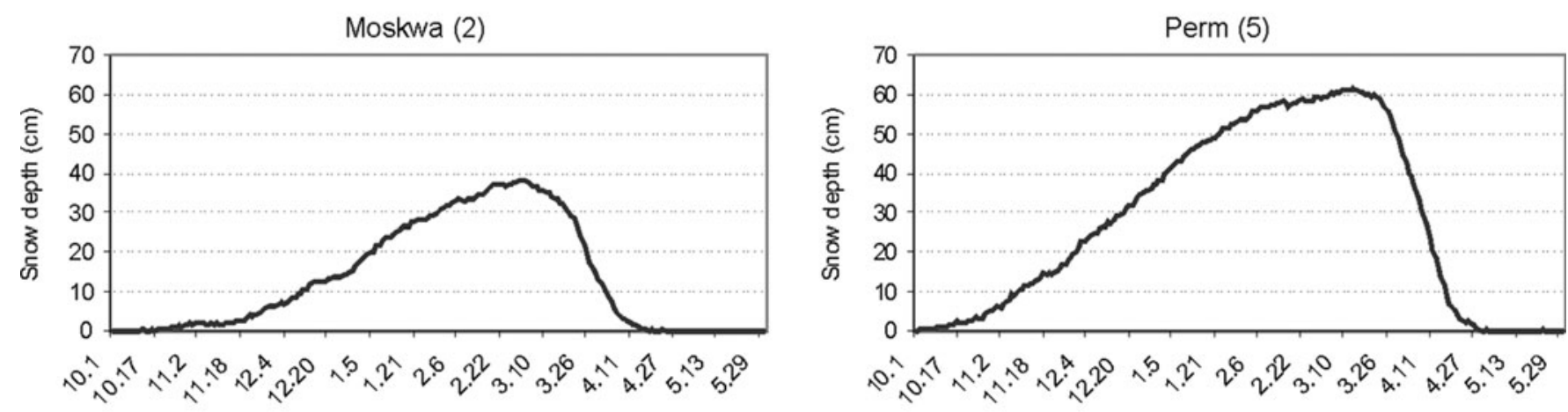

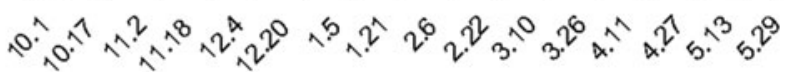
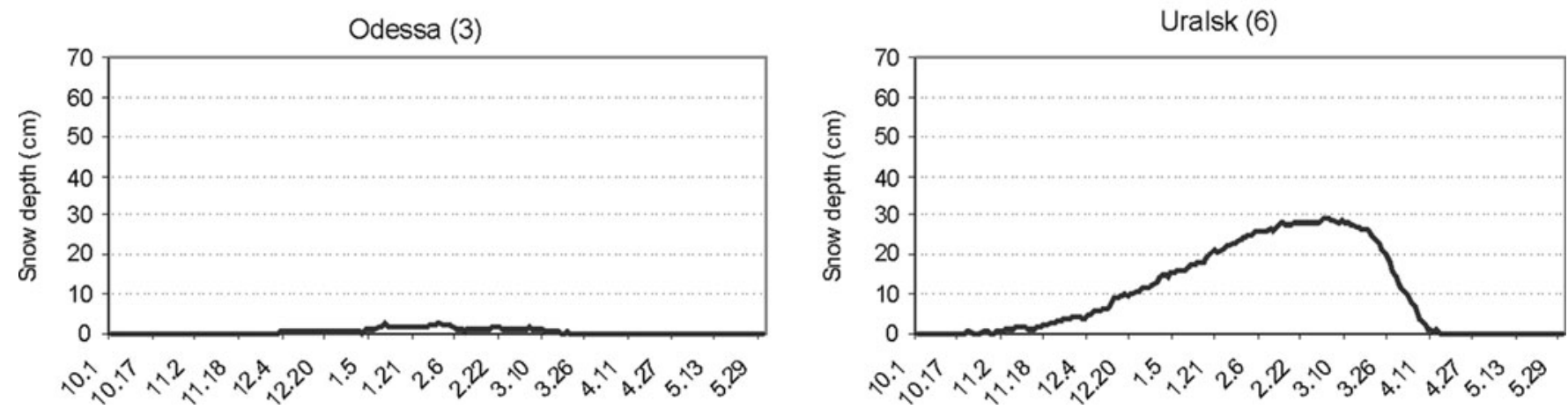

Fig. 6. Seasonal cycle of snow depth at selected stations, based on mean daily snow-depth values for the period 1951-95. For location of stations see Figure 1a.

monthly snow depth, and their variability explains no more than $17 \%$ of the monthly snow-depth variance. Only in the 'non-active' regions does it explain $40 \%$ in December and January.

\section{North Atlantic Oscillation spatial pattern}

In October, when the snow season starts in northeastern Europe, two circulation patterns bring snowfalls, one of them being the NAO. Its positive extremes result in rainfalls, as they are related to above-zero temperatures. In the negative NAO extremes, positive signals of increase in snow depth are observed north of $50^{\circ} \mathrm{N}$. Snow cover there is not permanent in October, as northeastern Europe is an 'active' snow region at that time of the year (Fig. 2).

From November, the NAO influence on snow cover spreads to the west of the study area. A significant correlation between the NAO index and the monthly snowfall totals was found in Lithuania, Latvia and Estonia. In January and March, the correlation coefficient $(r)$ exceeded -0.3 in Belarus and western Ukraine, and in Lithuania $r$ was lower than -0.5 in March.

During the positive NAO extremes, lower than normal snow-depth increases appeared in the western part of the study area and were strongest in March. Under the negative NAO extremes, strong positive signals were found in November, December and March.

In the western part of the study area, the correlation coefficient between the NAO index and the decrease in snow depth is significant in March and has the same sign as in the case of the increase within the 'active' snow regions. Correlations for the other months (December-February) were again negative for both the increase and decrease. In March, strong positive signals indicating intensive ablation were observed over Lithuania, Latvia and Estonia under the negative NAO extremes (Fig. 7). This may indicate that the air masses causing snowfalls in the western part of the former Soviet Union are also present during snow ablation. The other possibility is that the negative phase of the NAO causes great weather diversity over eastern Europe. In this instance, the monthly values may not be accurate enough to analyze the relationships between the circulation and the snowmelt processes, particularly within the 'active' snow regions, where snow cover is not persistent. The daily analysis for Kaliningrad seems to confirm the above findings.

In the 'non-active' regions, the correlation between the $\mathrm{NAO}$ index and decreases in snow depth was positive; 


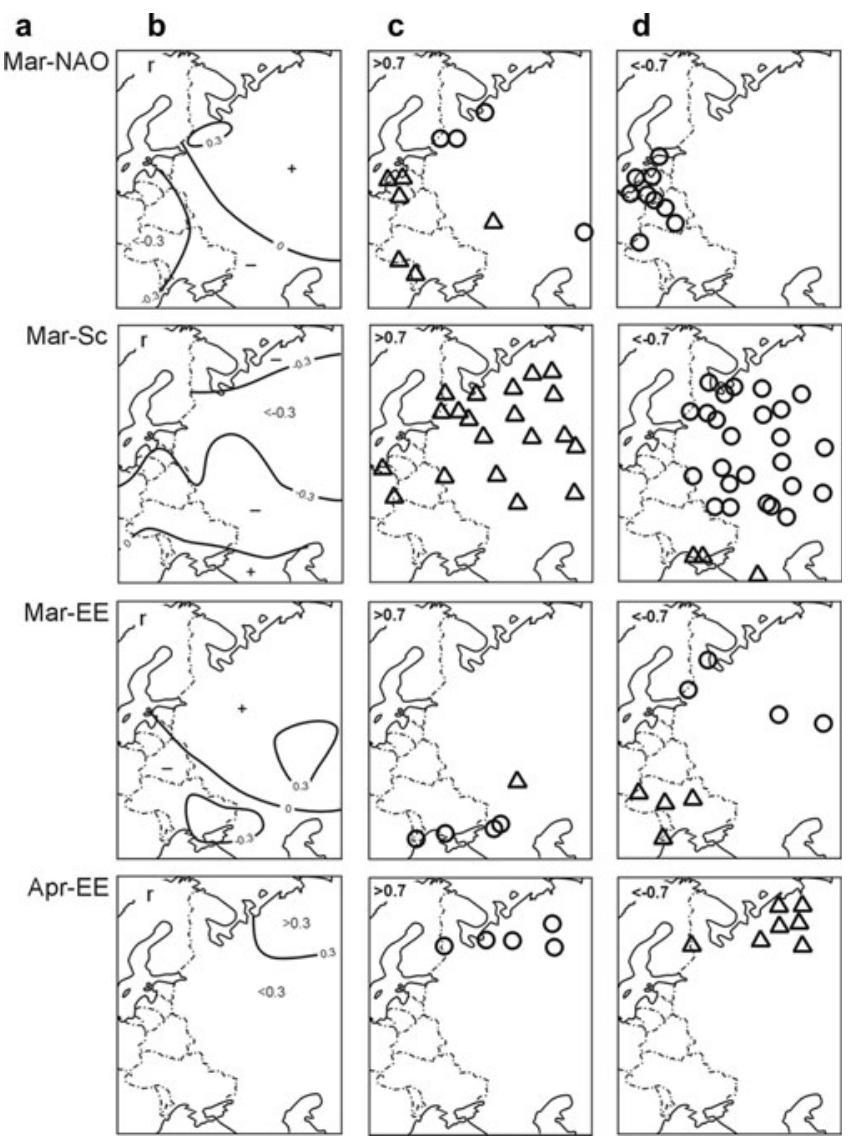

Fig. 7. Influence of circulation pattern on snow-depth decrease in spring: (a) monthly circulation pattern; (b) correlation coefficient between the rotated principal components and monthly decreases in snow depth; (c) decrease in snow depth under positive NAO extremes; and (d) decrease in snow depth under negative NAO extremes. Values higher than (mean $+1 \sigma)$ are indicated as circles; values lower than (mean-1 $\sigma$ ) are indicated as triangles. See Figures 2-4 for maps of circulation patterns.

$r>0.3$ in the area southwest of the White Sea. Rapid ablation was observed there in the NAO positive extremes. The NAO is the strongest pattern in every winter month, but its impact on changes in snow depth in eastern Europe is limited. A clear relationship between monthly snowfall totals and the NAO index was observed only at the beginning and end of winter (October, November, December, March), mainly in the western territory of the former Soviet Union. The relationship is weak in January and February, when the temperature is well below zero throughout the area. In that case, the positive NAO extremes do not cause warming above $0^{\circ} \mathrm{C}$ and do not result in rainfall. In March, the mean temperature is close to $0^{\circ} \mathrm{C}$ and the NAO has a strong impact on snow cover in most of the analyzed area of Europe (excluding the northeastern part). At that time, the positive NAO extremes bringing warm westerly flow prevent snow-cover formation. In the negative phase, lower than normal temperatures prevail over most of Europe, contributing to the occurrence of snow cover within the 'active' areas.

\section{Scandinavian spatial pattern}

In the positive SC phase an anticyclone over northern Scandinavia brings very cold and dry weather in eastern and northeastern Europe (Wibig, 1999a, b, c). This is a 'non- active' area of snow fluctuations from December to March. The temperature is constantly below $0^{\circ} \mathrm{C}$, and precipitation is the predominant factor contributing to the snow-cover development. This implies a significant negative correlation between the SC index and the monthly snowfall totals over that area. The correlation is lower than -0.5 along the Ural range (Fig. 3).

Under the negative SC mode, positive signals were found in the southeastern part of eastern Europe in January; positive tendencies also appear in the north. Opposite (negative) signals appear in the south again at the end of winter (March), when the westerly and southwesterly flow causes positive temperature anomalies.

In the positive SC phase, snowfalls were lower than average over most of the study area. At the same time, single positive signals of snow-depth increase were observed in the southwest. This may be connected with some negative temperature anomalies appearing under positive SC in southeastern Europe (Wibig, 2001). Frequent cyclone activity over Europe found by Clark and others (1999) in the positive phase of EU1, which is similar to SC, may foster snowfalls in the southwest of the study area.

In March, the northern anticyclone moves to the west, and its impact on fluctuations of snow depth changes. The negative phase of SC, causing westerly or southwesterly flows in most of Europe, favours ablation of snow over most of the study area (Fig. 7). Air masses coming from the west are usually warm but are also humid; thus also single positive signals of the increase in snow depth were found in eastern Europe under the negative extremes of the SC. Snowdepth changes were not rapid under the positive SC extremes in the west. Negative signals of both increases and decreases in the snow depth were observed close to the anticyclone centre.

\section{Eastern European spatial pattern}

In October the EE pattern exerts a strong impact on snowfalls in the east $(r<-0.5)$. Positive signals in the negative phase were found throughout the study area, except in the west and southwest where snowfall is rare at this time of the year. In the southeastern part of eastern Europe, early-autumn episodes of snow-cover appearance are usually connected with northerly flows. They appear in the western part of the cyclone formed over eastern Europe during the EE negative phase (Fig. 4). In November-January the eastern European anticyclone moves far to the southeast and is weakly related to the snowfalls in Europe. A significant correlation between the EE index and monthly snowfall totals appears only in northwestern Russia $(r>0.3)$ and over the Caspian Sea $(r<-0.3)$ in December. At that time, under the positive EE phase, some negative signals appear in the southeast, whereas positive tendencies were found in the northwest. In the negative EE phase, a single positive signal appears over the Caspian Sea; at the same time, monthly snowfall totals are below the critical value in the north. The situation changes in February and March. The anticyclone over eastern Europe corresponds to drier than normal conditions over most of the study area. Significant negative correlation coefficients between the EE index and monthly snowfall totals were found over the west and south.

The positive EE extremes inhibit the snowfalls, which become lower than the critical value in most of the stations located to the south of latitude $55^{\circ} \mathrm{N}$, where the northeasterly and easterly flows bring drier than normal weather 
$500 \mathrm{hPa}$

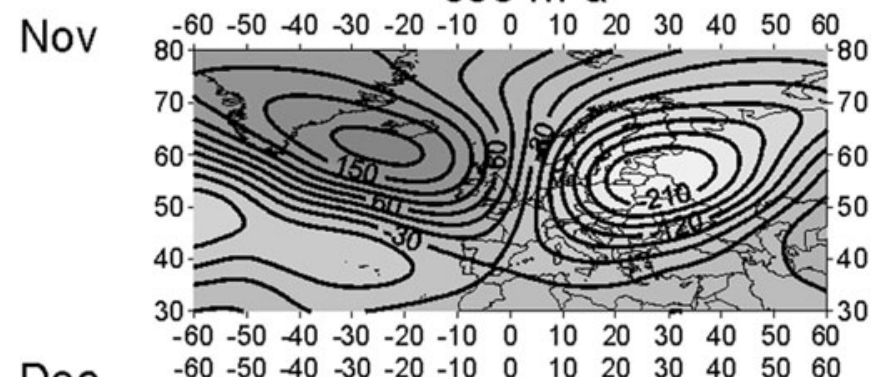

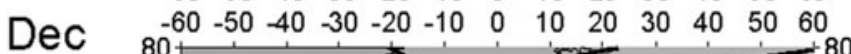

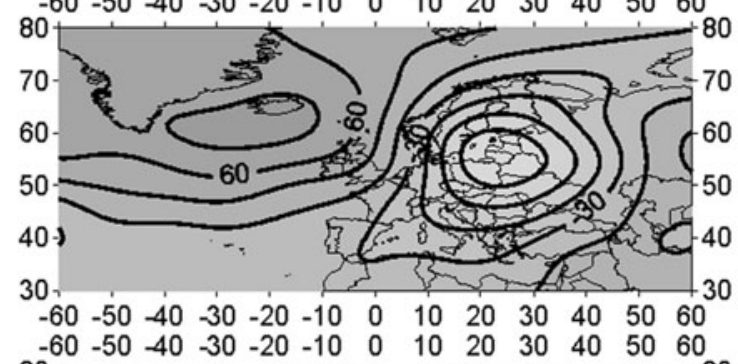

Jan

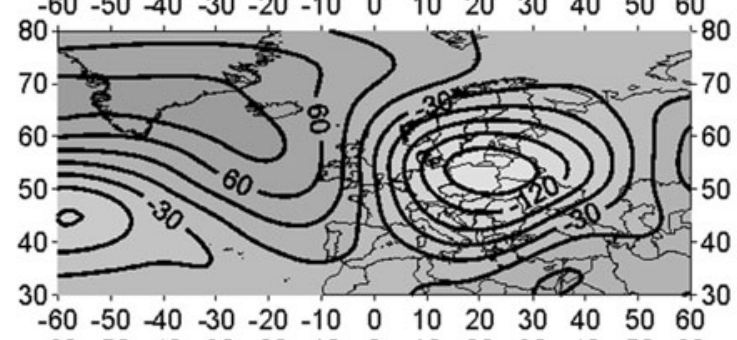

Feb $\quad-60 \begin{array}{cccccccccccc}-50 & -40 & -30 & -20 & -10 & 0 & 10 & 20 & 30 & 40 & 50 & 60\end{array}$

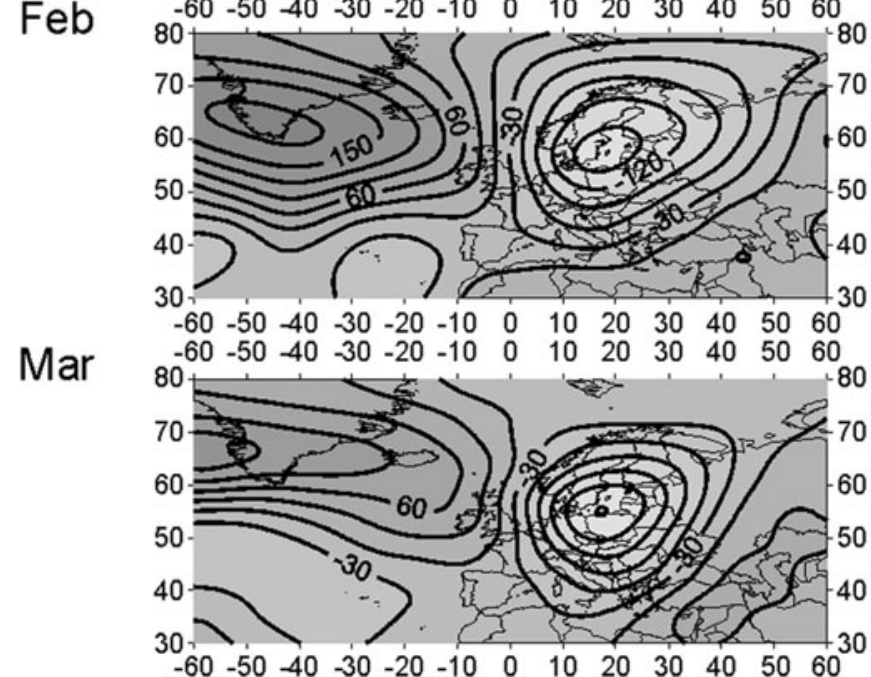

SLP

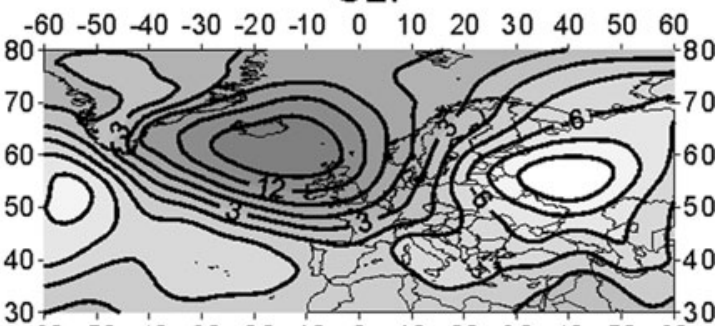

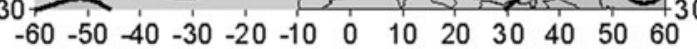

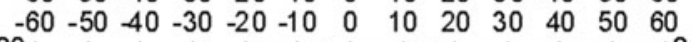

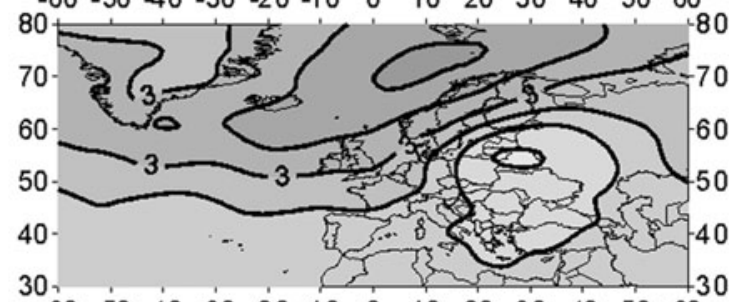

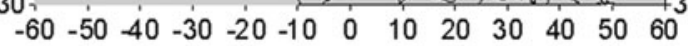

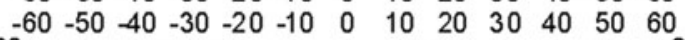

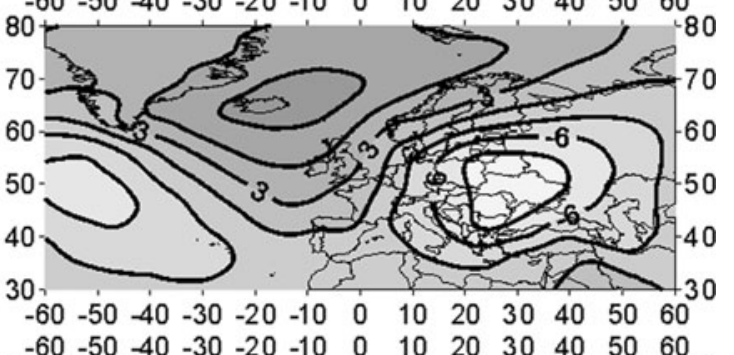

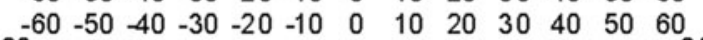

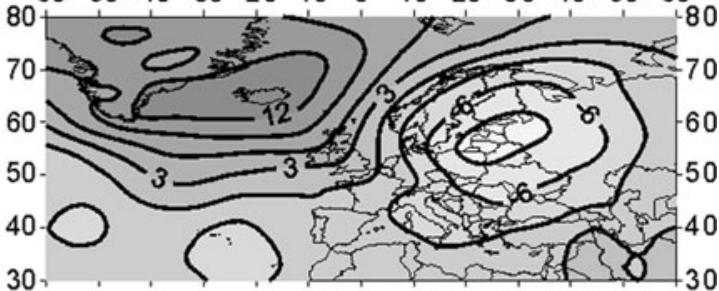

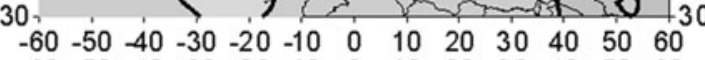

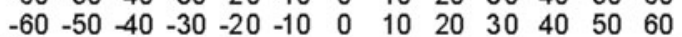

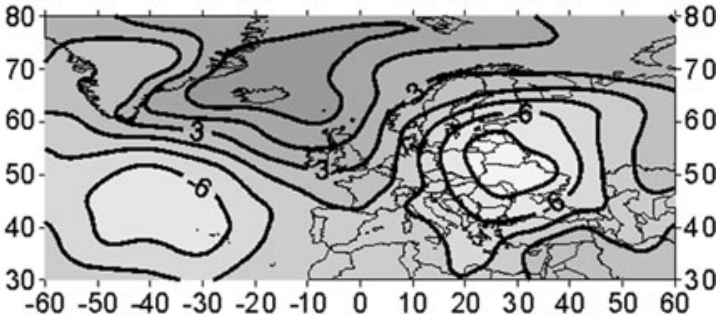

Fig. 8. Composite anomaly maps for the days with snow-depth increase $>5 \mathrm{~cm}$ in Kaliningrad.

conditions. Single opposite (positive) snow-cover signals appear in the northeast, where northwesterly humid flow prevails.

Under the negative EE extremes, lower than normal geopotential level over eastern Europe causes opposite circulation. In the southwest of the study area, northerly and northwesterly flow brings cold and humid air, which enhances snow-cover growth. Single opposite (negative) snow-cover signals found in the northeast are caused by easterly and southeasterly dry airflow.

In April, the EE circulation pattern is the only one that significantly affects snow-cover appearance. Its impact is limited to the 'active' snow area of eastern Europe (55$\left.65^{\circ} \mathrm{N}\right)$. In this area, the correlation coefficient between the EE index and the snow-depth increase is lower than -0.5 , and in the negative extremes snowfalls exceed the critical value. The anticyclone causing easterly airflows fades away in the positive phase. This brings warmer air masses from the southwest, causing the last winter snow cover to disappear (Fig. 7).

\section{Central European spatial pattern}

The correlation coefficient between the CE index and monthly snowfall totals is most significant in January. The strongest relationships appear right under the baric centre: the high in the positive phase and the low in the negative. In December and February, the analyzed area is to the east of the baric centre, and the discussed relationships are weaker (Fig. 5).

The blocking phase of the CE type (an anticyclone over Europe) brings dry weather and inhibits snowfalls over 
$500 \mathrm{hPa}$
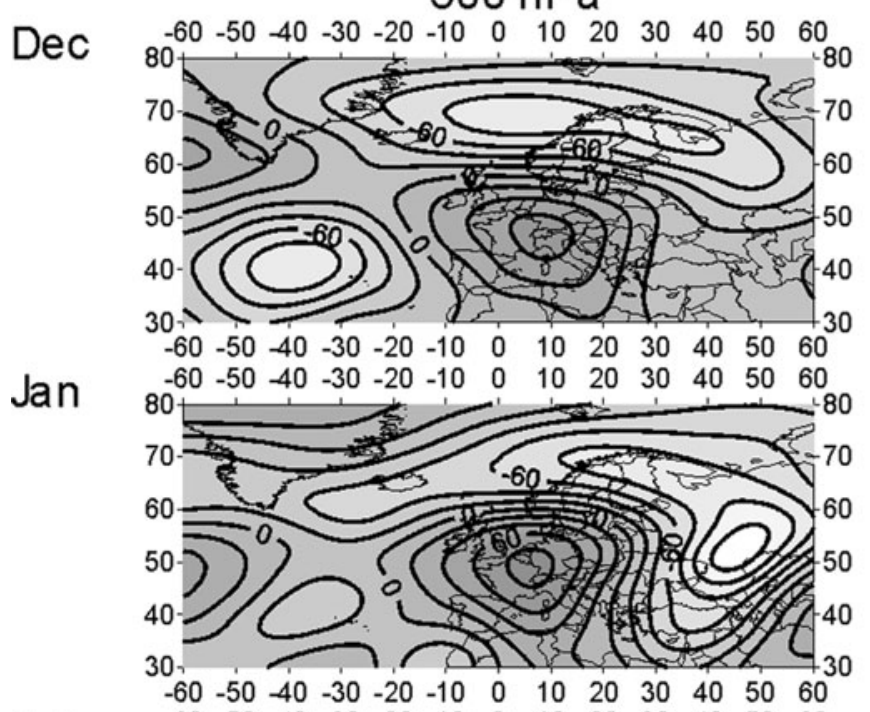

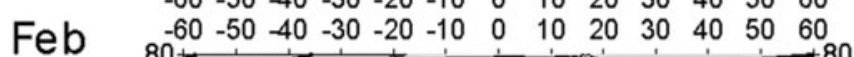

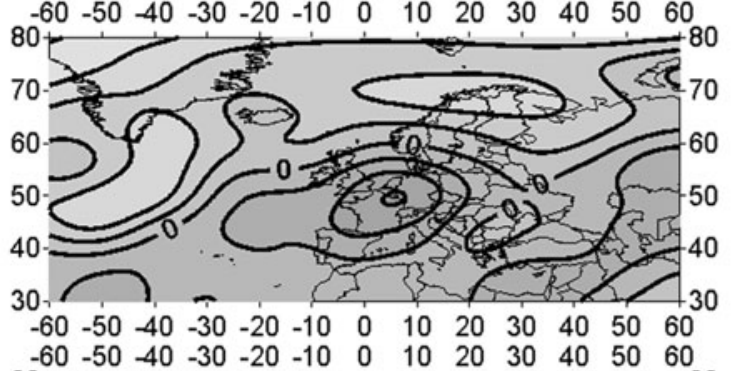

Mar

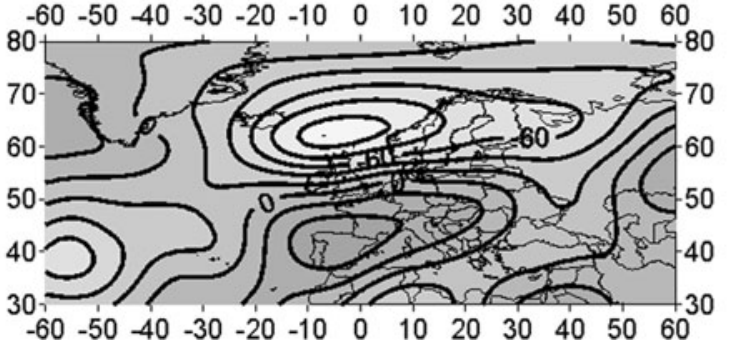

SLP
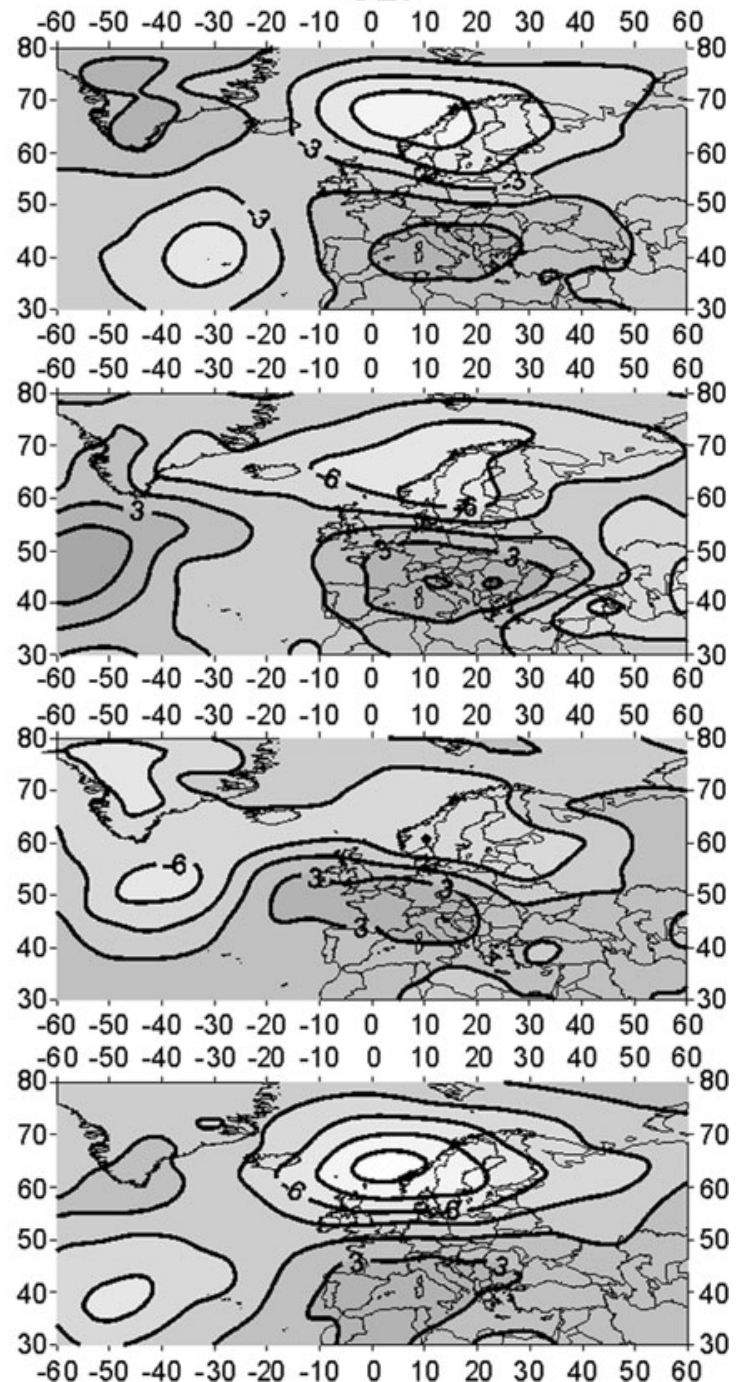

Fig. 9. Composite anomaly maps for the days with snow-depth decrease $>5 \mathrm{~cm}$ in Kaliningrad.

central and eastern Europe. Under the negative CE extremes, the temperature is lower than average (Wibig, 2001) and a cyclone spreads its activity over central Europe, resulting in strong positive snow-cover signals.

\section{Daily analysis}

The daily analysis was performed for three locations: Kaliningrad in the far west, representing an 'active' snow region, Ustcilma, situated in the northern area of a 'nonactive' snow region, and Uralsk in the southeastern part of the study area, representing the southern edge of a 'nonactive' snow region.

Composite anomaly maps constructed for the days with snowfalls in Kaliningrad show strong negative anomalies both at SLP and at $500 \mathrm{hPa}$ level, with a centre located directly above the station (Fig. 8). Lower pressure indicates stronger than usual cyclonic activity in this region. At the same time, positive anomalies appear over the North Atlantic (directly above Iceland at SLP), clearly resembling the negative NAO phase. The corresponding negative anomalies appear in the Azores region. Such a pressure pattern favours northerly flows, which are tantamount to a temperature drop in Europe. This confirms the findings of the monthly analysis concerning snowfalls in the western part of the study area.
A quite different circulation pattern is responsible for the ablation, which may occur throughout the winter, as the winter temperature in Kaliningrad may fluctuate above and below the melting point. Negative anomalies occur over the northeastern Atlantic and over Scandinavia, while higher than normal pressure and higher than normal $500 \mathrm{hPa}$ level are observed in central and southern Europe (Fig. 9). Such a pressure pattern causes strong westerly flow, bringing mild maritime air. The above-mentioned findings of the daily analysis of the ablation and circulation relationships in Kaliningrad show that monthly analysis of the snow-covercirculation relationships is not always precise enough, especially in the 'active' regions (e.g. compare the snowablation-NAO relationships in March).

Snowfalls in Uralsk are contingent upon strong negative anomalies of SLP and $500 \mathrm{hPa}$ levels with a centre located northwest of the station or directly above the station (SLP in November and March; Fig. 10). Such pressure patterns cause northwesterly flows both in the low and in the high troposphere, bringing cold and relatively humid air to southeastern Europe. These findings match the monthly analysis results. Negative anomalies over eastern Europe, i.e. lower than normal pressure, resemble the negative phase of the EE or sometimes the SC patterns (depending on the location of 
$500 \mathrm{hPa}$

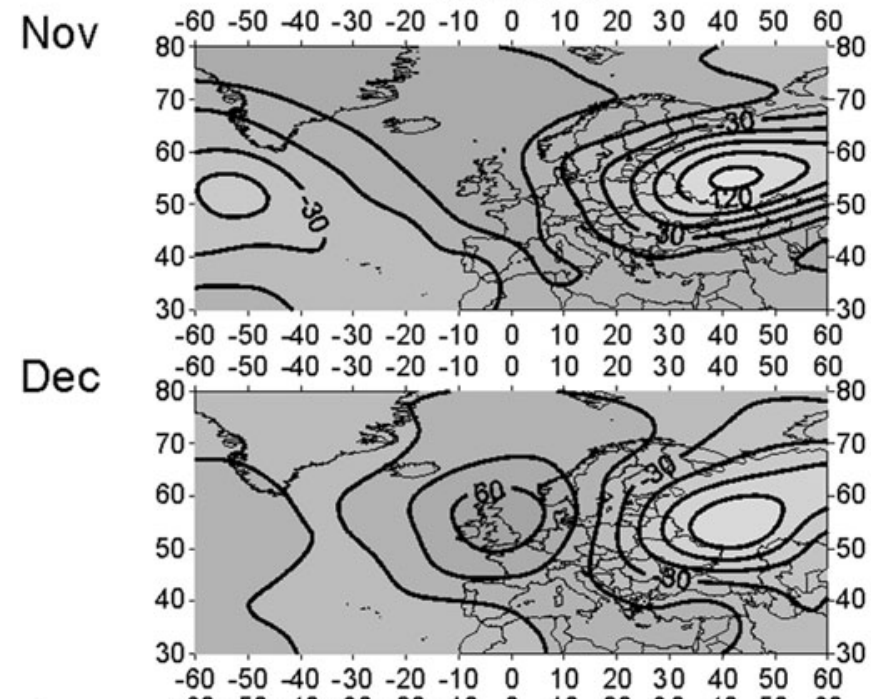

Jan $\quad-60 \quad-50 \begin{array}{ccccccccccc}-40 & -30 & -20 & -10 & 0 & 10 & 20 & 30 & 40 & 50 & 60\end{array}$

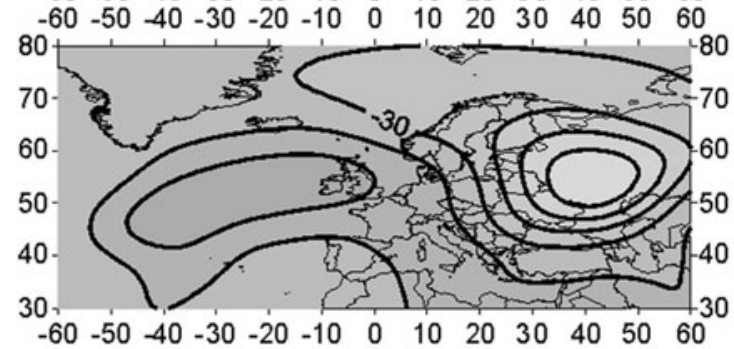

Feb $\quad-60 \begin{array}{lllllllllllll}-50 & -40 & -30 & -20 & -10 & 0 & 10 & 20 & 30 & 40 & 50 & 60\end{array}$

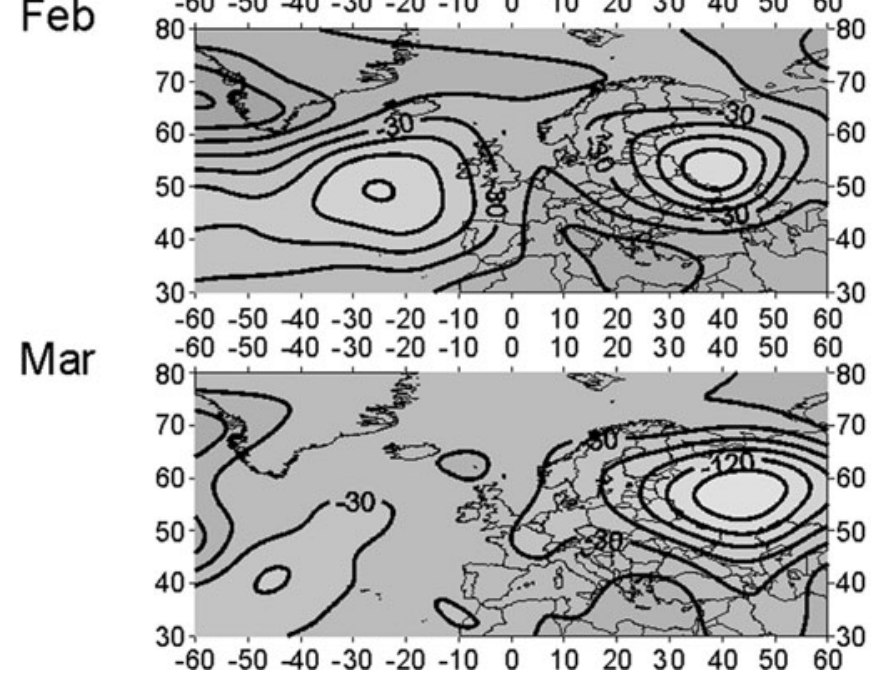

SLP
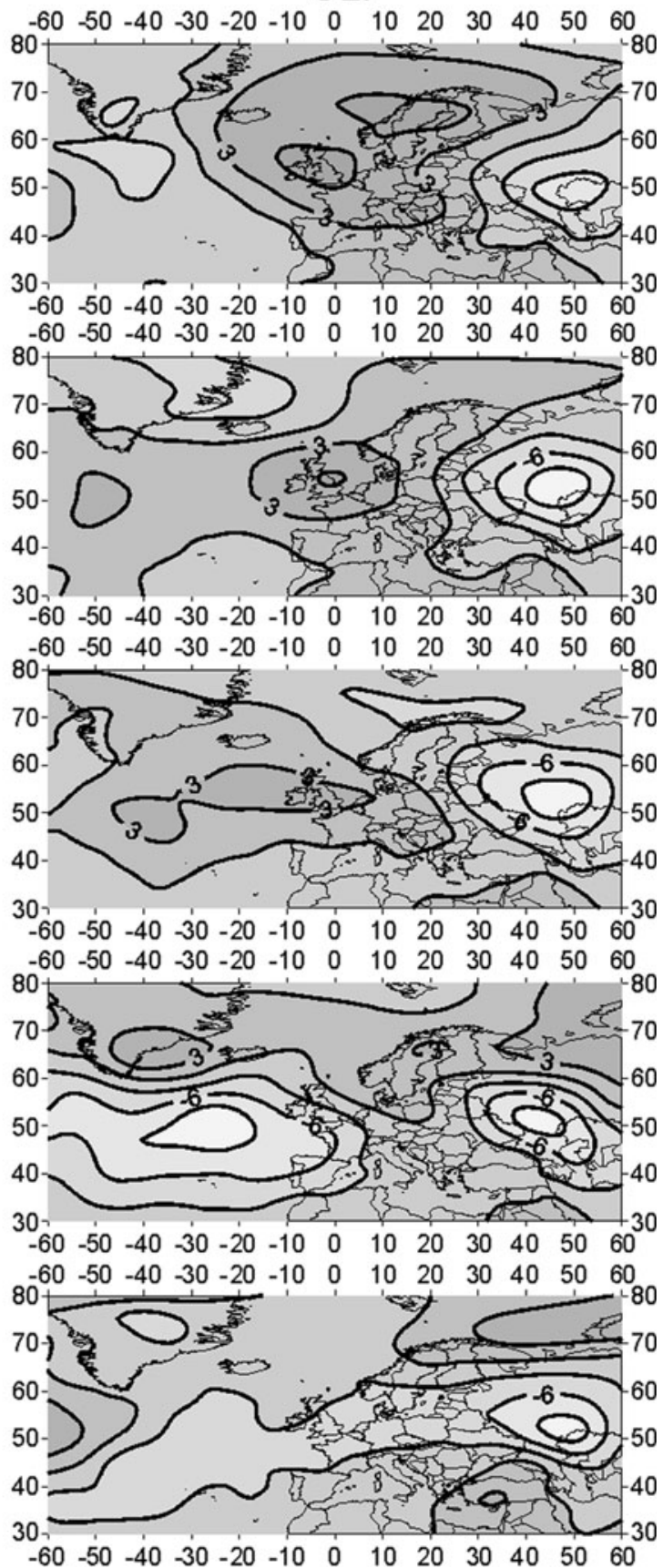

Fig. 10. Composite anomaly maps for the days with snow-depth increase $>5 \mathrm{~cm}$ in Uralsk.

the low-pressure centre), causing higher than normal snowfalls in the Uralsk region.

Ablation conditions in March and April indicate weak negative anomalies in the north (Scandinavia) and weak positive anomalies in southern Europe (Fig. 11). Such a pattern is also similar to the negative SC pattern which was confirmed to cause decreases in snow depth in the Uralsk region in March. There is no contradiction in the negative SC phase bringing snowfalls in winter months (DecemberFebruary) and causing thaws in spring. The depression over northern Scandinavia causes westerly flow. It brings snowfalls in the cold 'non-active' regions where the temperature is permanently well below zero and even relatively warm westerly air masses do not increase the temperature above the melting point. However, in the spring the warm air masses in the same direction may cause ablation.
In the northern regions of the analyzed area, represented by Ustcilma, snowfalls are also connected with negative SLP anomalies, whose centre is located directly above the station, while positive SLP anomalies spread over the rest of the continent (Fig. 12). This again indicates northwesterly flows, favourable for snowfalls. Weaker negative anomalies can be identified at the $500 \mathrm{hPa}$ level (excluding January and March, when the area of negative anomalies is shifted to the north), while the $500 \mathrm{hPa}$ level is higher than normal over most of the continent. The daily analysis confirms that snowfalls in the 'non-active' regions are related to circulation to a lesser extent than snowfalls in the warmer 'active' regions.

Spring thaws are caused by the opposite layout. Strong positive anomalies of $500 \mathrm{hPa}$ height are identified in northeastern Europe, while the $500 \mathrm{hPa}$ level is lower than usual over central Europe (Fig. 13). Similar but weaker layout 

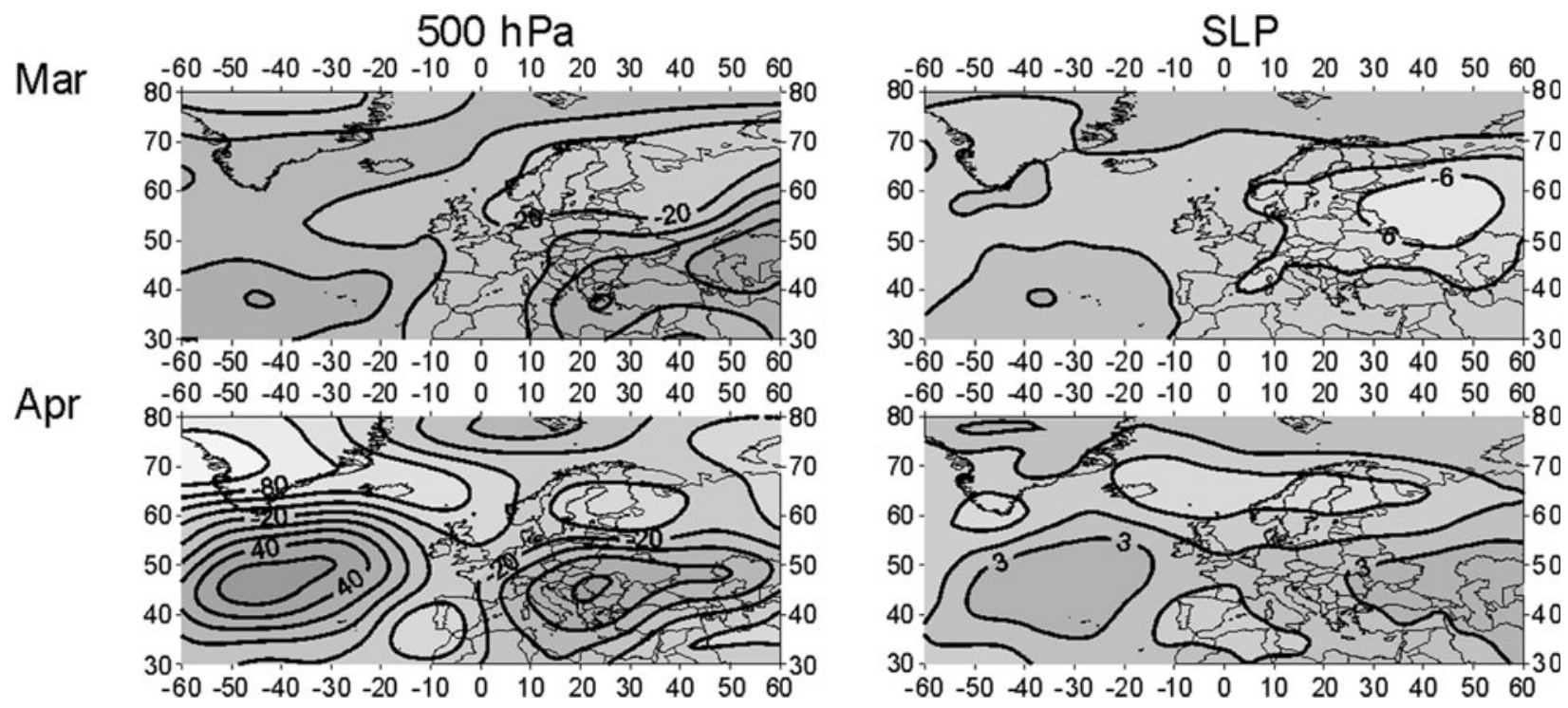

Fig. 11. Composite anomaly maps for the days with snow-depth decrease $>5 \mathrm{~cm}$ in Uralsk.

was identified in the SLP anomaly field. This is the case with the positive EE phase which, based on the monthly analysis, was confirmed to cause ablation. Such layouts of anomaly fields suggest anticyclonic conditions and southern advection of air masses.

\section{DISCUSSION AND CONCLUSIONS}

A much stronger impact of atmospheric circulation variability on snow depth is observed over the 'active' snowcover fluctuation zone than in the 'non-active' regions. The annual number of days with snow cover in the 'non-active' snow fluctuation zone, which spreads over Russia north to $50^{\circ} \mathrm{N}$, exceeds 150 (or even 200 in the far northeast) and is characterized by low variability $(<10 \%)$. Snow cover as a climatic parameter of low variability is not strongly sensitive to changes in the atmospheric circulation. Mean winter temperature in this region is constantly well below $-5^{\circ} \mathrm{C}$. Thus, precipitation is the main factor determining the snowcover increase. The only patterns that influence snowfalls in eastern and northeastern Europe are SC and EE.

The SC pattern is the most important for winter precipitation in northeastern Europe (Wibig, 1999a, b c), so it also has the greatest impact on snow-cover increase. In its positive phase, the anticyclone over northern Scandinavia brings northeasterly flow associated with very dry weather in northeastern Europe. In its negative phase, a depression over northern Scandinavia brings westerly or northwesterly flows. Relatively warm western air masses do not cause thaws in mid-winter, when the temperature in the northeast is below $-10^{\circ} \mathrm{C}$, but in the spring the same warm air masses may cause ablation. Cyclone activity in the north in the negative phase of SC may foster snowfalls in eastern and northeastern Europe. The daily analysis for Ustcilma, which represents a 'non-active' region, confirms the aforementioned findings. Snowfalls in the northeast are connected with negative anomalies of SLP, whose centre is located to the north of the station, while positive SLP anomalies spread over the rest of the continent. Negative extremes of EE inhibit snowfalls in the 'non-active' regions. In this case, cyclones locate over eastern or southeastern Europe and cause southerly or southeasterly warm airflows.
The 'active' snow-cover regions are characterized by a great diversity of snow cover (20-50\% diversity in the number of days with snow cover (Bednorz, 2004)). As the snow cover there is not stable, it is more sensitive to the variability in atmospheric circulation. Temperature is an important factor for snow-cover occurrence in central Europe (Hantel and others, 2000). The southeastern part of the continent is characterized by low winter precipitation. Therefore, the inflow of humid air masses seems to be an equally important factor affecting snow cover forming as the temperature drops. According to Jaagus and others (2003), winter temperature in southeastern Europe is not very sensitive to the air circulation, and the circulation patterns do not affect the length of the thermal winter.

The EE circulation pattern has the greatest importance for snowfall occurrence within the 'active' snow fluctuation zones in February. A high geopotential level over the Black Sea results in above-normal temperatures in most of central and eastern Europe, preventing snow cover from forming. Similar conditions are observed under the blocking phase of the CE type, particularly in January, when the anticyclone is located over central Europe. Under the opposite EE phase, when the anticyclone declines and the geopotential level is below its normal value, the northerly flow brings cold air to central and southeastern Europe. Despite dry conditions prevailing over most of Europe (apart from the southeastern shores), the snowfall totals are higher than average. In spring, EE is the only circulation pattern that significantly affects snow-cover fluctuations over the 'active' snow area, which is limited to northeastern Europe.

According to daily analysis performed for Uralsk, located in the southern part of the 'active' snow-cover region, snowfalls are contingent upon strong negative anomalies of SLP and $500 \mathrm{hPa}$ levels with a centre located northwest of or directly above the station. These findings match the results of the monthly analysis. Lower than normal pressure over eastern Europe resembles the negative phase of the $\mathrm{EE}$ or sometimes the SC pattern (depending on the location of the low-pressure centre), which was confirmed to cause higher than normal snowfalls in the Uralsk region.

The NAO is the best-recognized circulation pattern determining winter temperature and precipitation (Hurrell, 
$500 \mathrm{hPa}$

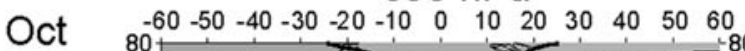
10.

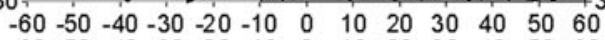

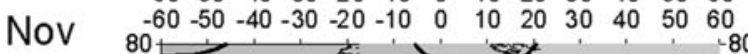

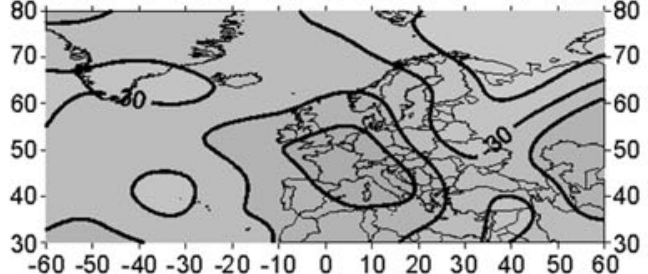

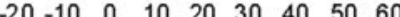

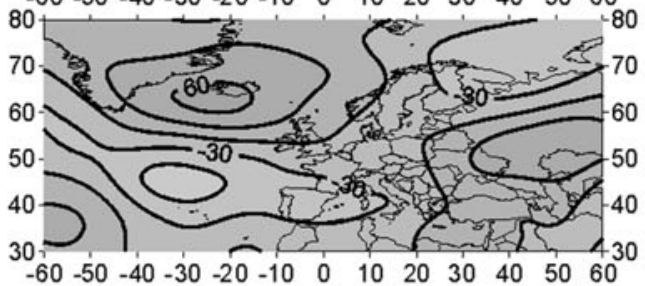

Jan $\quad 80-60-50-40-30-20-10 \quad 0 \quad 10 \quad 2030 \quad 40 \quad 50 \quad 60$

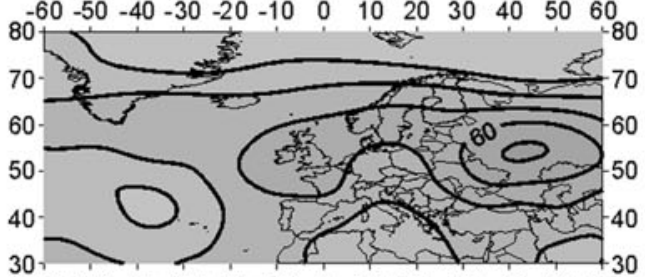

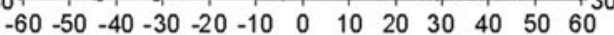

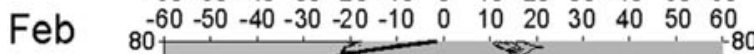

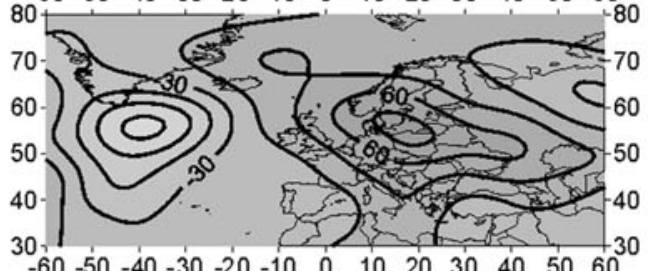

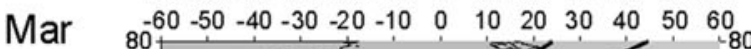

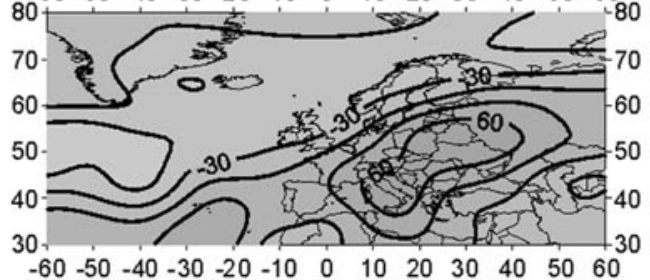

Apr $\quad 80-60-50-40-30-20-10 \quad 0 \quad 10 \begin{array}{lllllll}-60 & -20 & 30 & 40 & 50 & 60\end{array}$

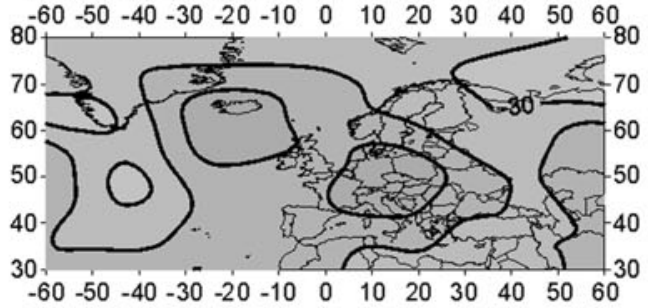

$-60-50-40-30-20-10 \quad 0 \quad 10 \quad 20 \quad 30 \quad 40 \quad 50 \quad 60$

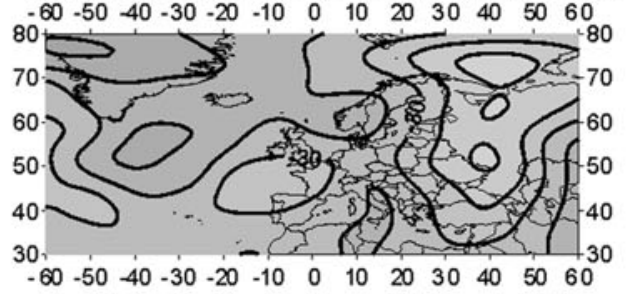

SLP

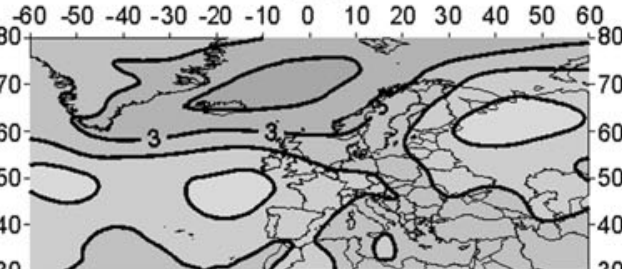

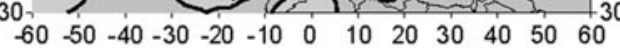

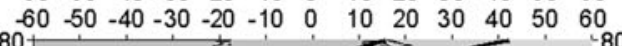

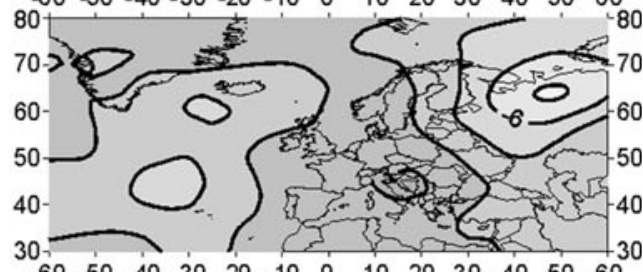
$\begin{array}{lllllllllllll}30 & -50 & -40 & -30 & -20 & -10 & 0 & 10 & 20 & 30 & 40 & 50 & 60\end{array}$

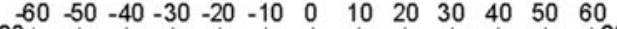

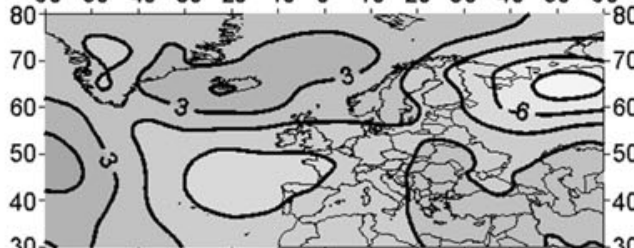

$30-50-40-30-20-10 \quad 0 \quad 1020304050$ - 30

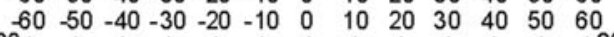

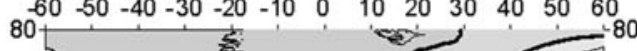
30-

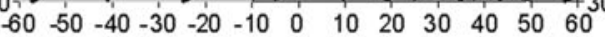

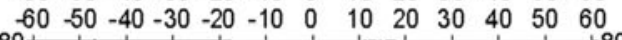

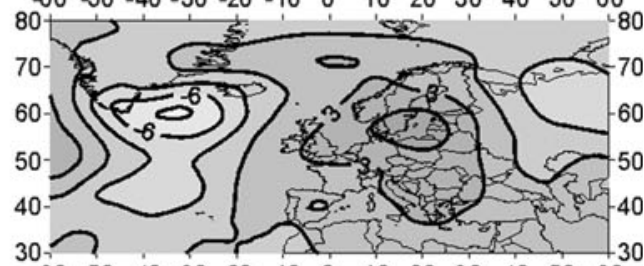

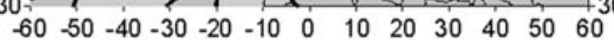

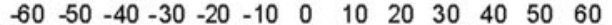

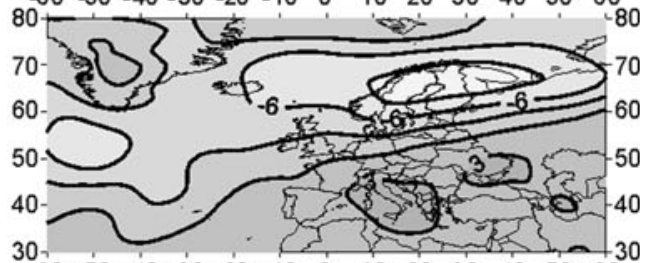

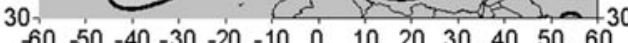

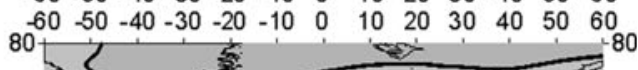
10-10-

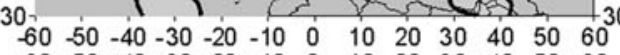

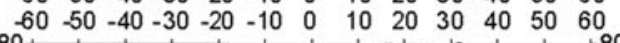

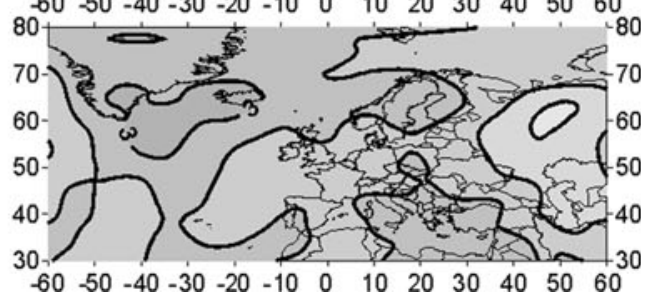

Fig. 12. Composite anomaly maps for the days with snow-depth increase $>5 \mathrm{~cm}$ in Ustcilma. 
$500 \mathrm{hPa}$

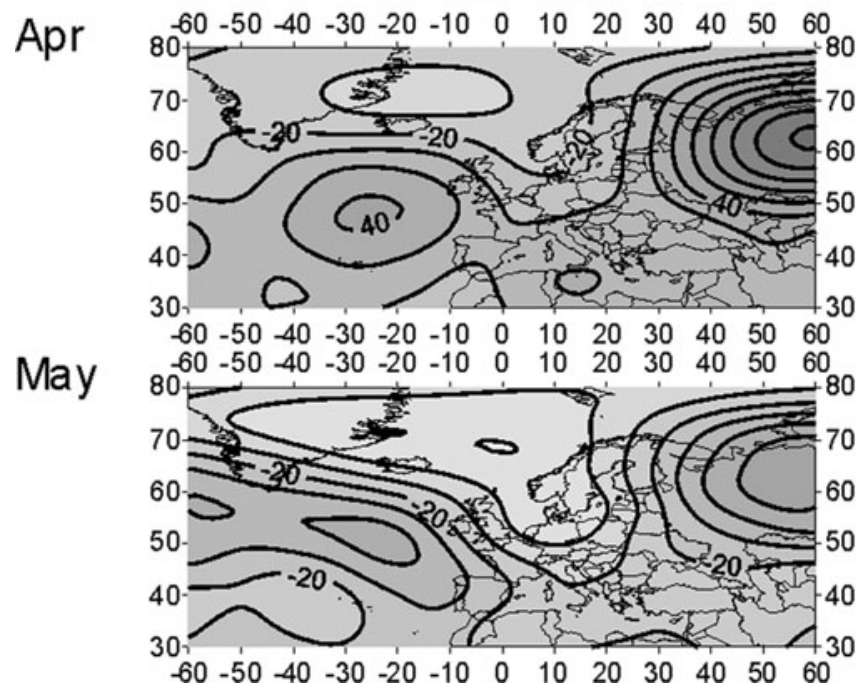

SLP

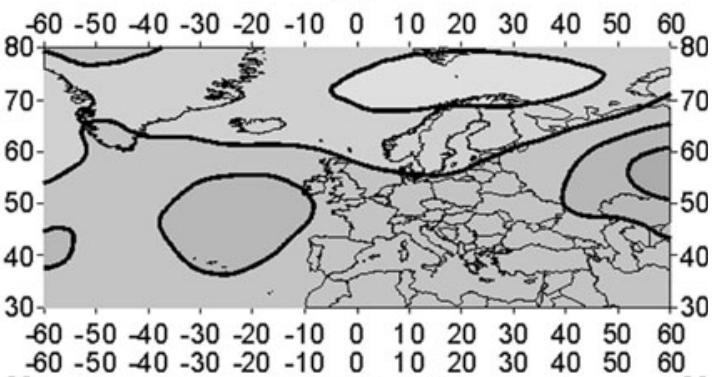

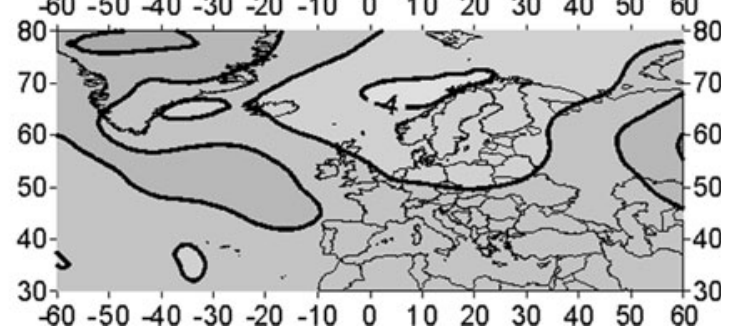

Fig. 13. Composite anomaly maps for the days with snow-depth decrease $>5 \mathrm{~cm}$ in Ustcilma.

1995; Hurrell and Van Loon, 1997; Wibig, 1999a, b, c, 2001). Clark and others (1999) detected significant snowcover signals in the 'active' snow regions in central Europe under the NAO positive phase. Gutzler and Rosen (1992) found strong relationships between the snow-cover extent in Europe and the NAO-like circulation pattern; this relationship weakens east of $30^{\circ} \mathrm{E}$. This study confirms that under the positive NAO phase the southwesterly flow causes a higher temperature, suppressing snow-cover formation in the eastern part of central Europe (Bednorz, 2002, 2004). In the negative phase, lower than normal temperature prevails over most of Europe, contributing to snow-cover growth within the 'active' areas. However, this rule applies to areas with the mean temperature close to $0^{\circ} \mathrm{C}$. If the mean temperature is well below zero, it rarely or never exceeds the melting point in the positive NAO phase and does not affect the snow cover. This limits the spatial and temporal impact of NAO on snow-cover development. This influence is most significant in the western part of the study area at the beginning and at the end of winter.

Daily analysis for Kaliningrad confirms the negative correlation between snowfalls and the NAO index. Snowfalls in Kaliningrad are related to cyclonic activity in this region and positive anomalies of SLP over the North Atlantic (directly above Iceland). At the same time, negative anomalies appear in the Azores region. This pressure pattern resembles the negative NAO phase.

Decreases in snow-cover depth are weakly related to atmospheric circulation. Clark and others (1999) found coherent snow signals associated with the EU1 circulation mode in southeastern Europe, where significant decreases in snow cover occur with positive EU1 extremes. This corresponds to weak negative signals of snow-depth increase in this region, obtained in this study under the positive SC extremes. Under the negative EU1 extremes, the snow cover seems to be enhanced in southeastern Europe (Clark and others, 1999). This was confirmed only for December and January in this study. Clark and others (1999) found negative snow-cover signals in both the positive and negative SC extremes in central Europe.

Daily analysis has demonstrated that snowmelt in the 'active' regions over the whole snow season is related to westerly airflows. In the 'non-active' areas the spring ablation is caused by westerly or southerly flows and anticyclonal conditions, which favour sunny weather. These results correspond to the findings of Rikiishi and Sakakibara (2004) who invesigated snow-depth changes in the former Soviet Union and their relationship with atmospheric circulation. They found that snowfall intensities are controlled mainly by atmospheric circulation, whereas snowmelt strongly depends on the solar radiation in springtime.

\section{ACKNOWLEDGEMENT}

J. Wibig's work was supported by the Polish Ministry of Science and Higher Education under the grant SPB STATME.

\section{REFERENCES}

Armstrong, R. 2001. Historical Soviet Daily Snow Depth version 2 (HSDSD). Boulder, CO, University of Colorado. Cooperative Institute for Research in Environmental Sciences. National Snow and Ice Data Center. CD-ROM.

Barnston, A.G. and R.E. Livezey. 1987. Classification, seasonality, and persistence of low-frequency atmospheric circulation patterns. Mon. Weather Rev., 115(6), 1083-1126.

Bednorz, E. 2002. Snow cover in western Poland and macro-scale circulation conditions. Int. J. Climatol., 22(5), 533-541.

Bednorz, E. 2004. Snow cover in eastern Europe in relation to temperature, precipitation and circulation. Int. J. Climatol., 24(5), 591-601.

Birkeland, K.W. and C.J. Mock. 1996. Atmospheric circulation patterns associated with heavy snowfall events, Bridger Bowl, Montana, U.S.A. Mt. Res. Dev., 16(3), 281-286.

Brown, R.D. and B.E. Goodison. 1996. Interannual variability in reconstructed Canadian snow cover, 1915-1992. J. Climate, 9(6), 1299-1318.

Carleton, A.M. 1988. Meridional transport of eddy sensible heat in winters marked by extremes of the North Atlantic Oscillation, 1948/49-1979/80. J. Climate, 1(2), 212-223.

Cayan, D.R. 1996. Interannual climate variability and snowpack in the western United States. J. Climate, 9(5), 928-948.

Clark, M.P., M.C. Serreze and D.A. Robinson. 1999. Atmospheric controls on Eurasian snow extent. Int. J. Climatol., 19(1), 27-40.

Falarz, M. 2002. Wieloletnia zmienność pokrywy żnieżnej w Polsce na tle zmian cyrkulacyjnych, termicznych i opadowych 
[Multiannual snow cover variability in Poland at the background of changes in circulation, temperature and precipitation]. ( $\mathrm{PhD}$ thesis, Jagiellonian University.)

Frei, A. 1997. Towards a snow cover fingerprint for climate change detection. (PhD thesis, Rutgers University.)

Frei, A. and D.A. Robinson. 1999. Northern Hemisphere snow extent: regional variability 1972-1994. Int. J. Climatol., 19(14), $1535-1560$.

Gutzler, D.S. and R.D. Rosen. 1992. Interannual variability of wintertime snow cover across the Northern Hemisphere. J. Climate, 5(12), 1441-1447.

Hantel, M., M. Ehrendorfer and A. Haslinger. 2000. Climate sensitivity of snow cover duration in Austria. Int. J. Climatol., 20(6), 615-640.

Horel, J.D. 1981. A rotated principal component analysis of the interannual variability of the northern hemisphere $500 \mathrm{mb}$ height field. Mon. Weather Rev., 109(10), 2080-2092.

Hurrell, J.W. 1995. Decadal trends in the North Atlantic Oscillation: regional temperatures and precipitation. Science, 269(5224), 676-679.

Hurrell, J.W. and H. van Loon. 1997. Decadal variations in climate associated with the North Atlantic Oscillation. Climatic Change, 36(3-4), 301-326.

Jaagus, J., J. Truu, R. Ahas and A. Aasa. 2003. Spatial and temporal variability of climatic seasons on the East European Plain in relation to large-scale atmospheric circulation. Climate Res., 23(2), 111-129.

Kaiser, H.F. 1958. The Varimax criterion for analytic rotation in factor analysis. Psychometrika, 23(3), 187-200.

Kalnay, E. and 21 others. 1996. The NCEP/NCAR 40-year reanalysis project. Bull. Am. Meteorol. Soc., 77(3), 437-471.

Leathers, D.J. and D.A. Robinson. 1997. Abrupt changes in the seasonal cycle of North American snow cover. J. Climate, 10(10), 2569-2585.

Nowosad, M. 1992. The dynamics of snow cover depth depending on the types of atmospheric circulation on the example of the
Bieszczady Mountains. Lublin, Maria Skłodowska University Press.

Rikiishi, K. and J. Sakakibara. 2004. Seasonal cycle of the snow coverage in the former Soviet Union and its relation with atmospheric circulation. Ann. Glaciol., 38, 106-114.

Rogers, J.C. 1990. Patterns of low-frequency monthly sea level pressure variability (1899-1986) and associated wave cyclone frequencies. J. Climate, 3(12), 1364-1379.

Serreze, M.C., F. Carse, R.G. Barry and J.C. Rogers. 1997. Icelandic low cyclone activity: climatological features, linkages with the $\mathrm{NAO}$, and relationships with recent changes in the northern hemisphere circulation. J. Climate, 10(3), 453-464.

Serreze, M.C., M.P. Clark, D.L. McGinnis and D.A. Robinson. 1998. Characteristics of snowfall over the eastern half of the United States and relationships with principal modes of lowfrequency atmospheric variability. J. Climate, 11(2), 234-250.

Wibig, J. 1999a. Cyrkulacja atmosferyczna nad Europą na powierzchni izobarycznej $500 \mathrm{hPa}$. Część 1: Zima [Atmospherical circulation over Europe at $500 \mathrm{hPa}$ isobaric level. Part 1: winter]. Prz. Geofiz., 44(1-2), 15-24.

Wibig, J. 1999b. Cyrkulacja atmosferyczna nad Europą na powierzchni izobarycznej $500 \mathrm{hPa}$. Część 2: Wiosna, lato, jesień [Atmospherical circulation over Europe at $500 \mathrm{hPa}$ isobaric level. Part 2: spring, summer, autumn]. Prz. Geofiz., $\mathbf{4 4}(1-2), 25-38$.

Wibig, J. 1999c. Precipitation in Europe in relation to circulation patterns at the $500 \mathrm{hPa}$ level. Int. J. Climatol., 19(3), 253-269.

Wibig, J. 2000. Oscylacja północnoatlantycka i jej wpływ na kształtowanie pogody i klimatu [The North Atlantic Oscillation and its impact on weather and climate]. Prz. Geofiz., 45(2), 120-137.

Wibig, J. 2001. Wpływ cyrkulacji atmosferycznej na rozkład przestrzenny anomalii temperatury i oṕadów w Europie [Influence of atmospheric circulation on the spatial distribution of temperature and precipitation anomalies in Europe]. Łódź Wydawnictwo Uniwersytetu Łódzkiego. 